LBNL-54244

\title{
Life-cycle Cost and Payback Period Analysis for Commercial Unitary Air Conditioners
}

\author{
Greg Rosenquist, Katie Coughlin, Larry Dale, James McMahon, Steve Meyers \\ Energy Analysis Department \\ Environmental Energy Technologies Division \\ Ernest Orlando Lawrence Berkeley National Laboratory \\ University of California \\ Berkeley, CA 94720
}

March 2004

This work was supported by the Office of Building Technologies of the U.S. Department of Energy, under Contract No. DE-AC03-76SF00098. 


\begin{abstract}
This report describes an analysis of the economic impacts of possible energy efficiency standards for commercial unitary air conditioners and heat pumps on individual customers in terms of two metrics: life-cycle cost (LCC) and payback period (PBP). For each of the two equipment classes considered, the 11.5 EER provides the largest mean LCC savings. The results show how the savings vary among customers facing different electricity prices and other conditions. At $11.5 \mathrm{EER}$, at least $80 \%$ of the users achieve a positive LCC savings. At 12.0 EER, the maximum efficiency analyzed, mean LCC savings are lower but still positive. For the $\geq 65,000 \mathrm{Btu} / \mathrm{h}$ to $<135,000 \mathrm{Btu} / \mathrm{h}$ equipment class, $59 \%$ of users achieve a positive LCC savings. For the $\geq 135,000 \mathrm{Btu} / \mathrm{h}$ to $<240,000 \mathrm{Btu} / \mathrm{h}$ equipment class, $91 \%$ of users achieve a positive LCC savings.
\end{abstract}




\section{TABLE OF CONTENTS}

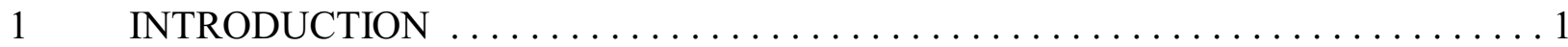

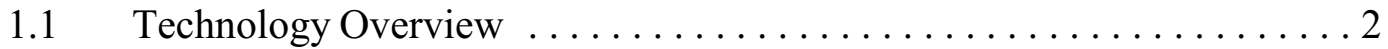

1.2 General Approach for LCC and PBP Analysis $\ldots \ldots \ldots \ldots \ldots \ldots$

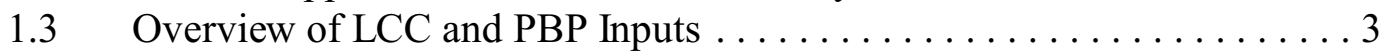

1.4 Use of Whole-Building Simulations in LCC and PBP Analysis . 8

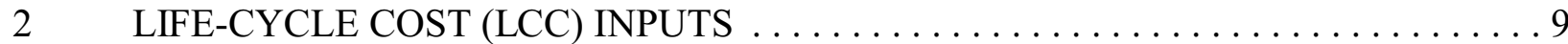

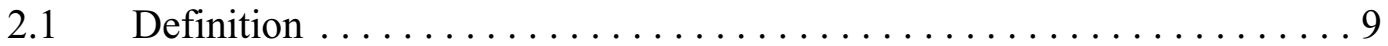

2.2 Total Installed Cost Inputs $\ldots \ldots \ldots \ldots \ldots \ldots \ldots \ldots \ldots$

2.2.1 Baseline Manufacturer Price . . . . . . . . . . . . . . . . . . . . 10

2.2.2 Standard-level Manufacturer Price Increases . . . . . . . . . . . . . . . 11

2.2 .3 Overall Markup . . . . . . . . . . . . . . . . . . . . . . . . 12

2.2 .4 Installation Cost . . . . . . . . . . . . . . . . . . . 13

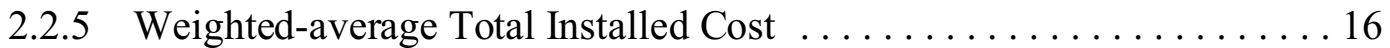

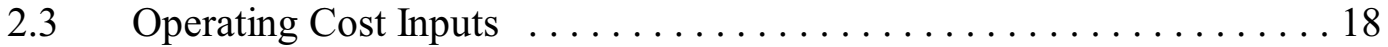

2.3.1 Electricity Price Analysis . . . . . . . . . . . . . . . . . . . . . 19

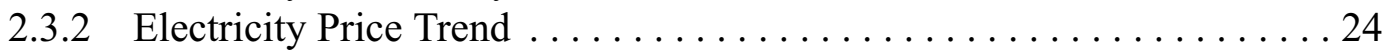

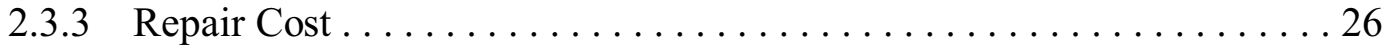

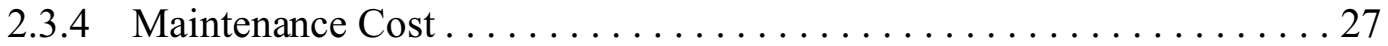

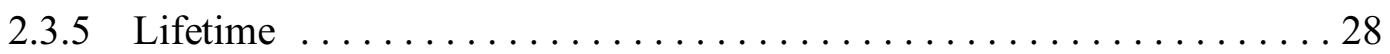

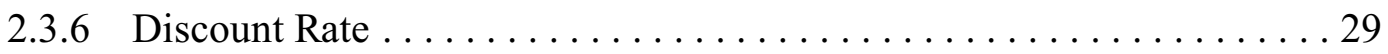

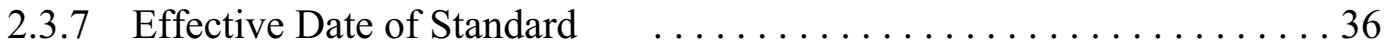

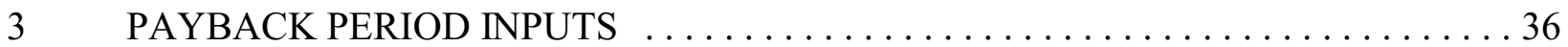

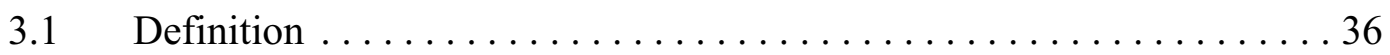

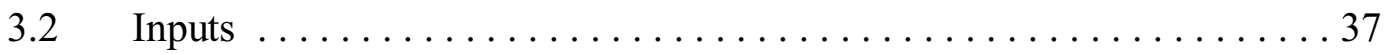

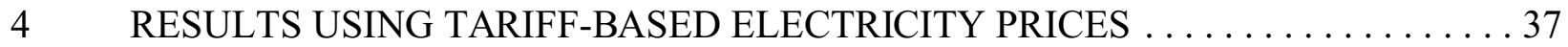

$4.1 \quad$ LCC Results . . . . . . . . . . . . . . . . . . . . . . . . . 37

4.1.1 LCC Breakdown Based Upon Average Input Values . . . . . . . . . . 37

4.1 .2 Baseline LCC Distributions . . . . . . . . . . . . . . . . . . 40

4.1.3 Differences in LCC Between Baseline and Standard EER Level

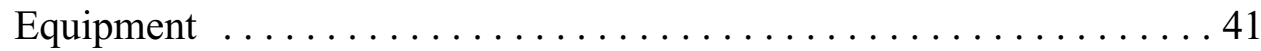

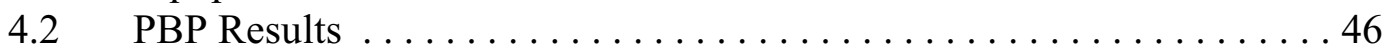

5 RESULTS USING HOURLY-BASED ELECTRICITY PRICES $\ldots \ldots \ldots \ldots \ldots$

$5.1 \quad$ LCC Results . . . . . . . . . . . . . . . . . . . . . . . . 50

5.1 .1 LCC Breakdown Based upon Average Input Values . . . . . . . . . . . . . 50

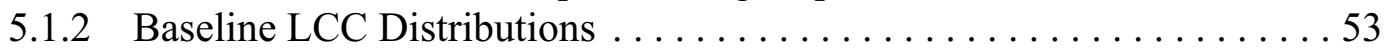

5.1.3 Differences in LCC Between Baseline and Standard EER Level Equipment ............................. 54

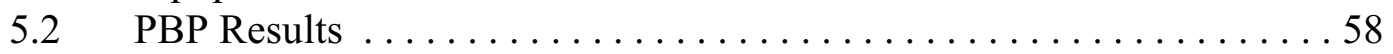

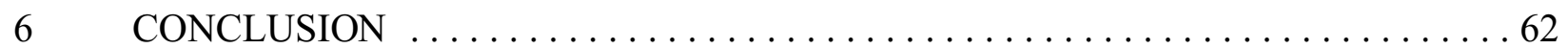

\section{LIST OF TABLES}


Table 1 Summary Information of Inputs for the Determination of LCC and PBP

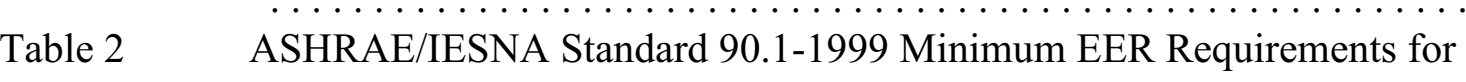

Table 3

Commercial Unitary Air Conditioners . . . . . . . . . . . . . . . . 11

Table 4

Table 5

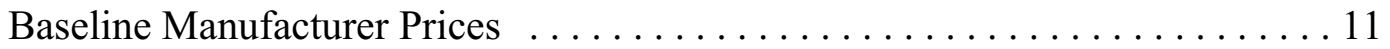

Table 6

Table 7

Table 8

Table 9

Standard-level Manufacturer Price Increases . . . . . . . . . . . . . . . . 12

Overall Baseline Markups . . . . . . . . . . . . . . . . . . . 13

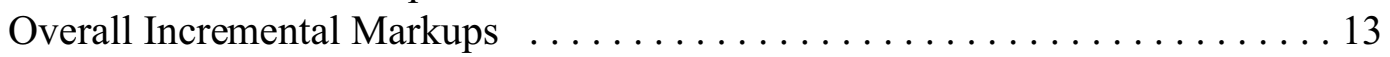

Installation Costs for Baseline Efficient Air Conditioners $\ldots . \ldots \ldots \ldots \ldots 14$

Installation Cost Indices (National Value $=100.0) \ldots \ldots \ldots \ldots \ldots$

Costs and Markups for Determination of Weighted-Average Total Installed Costs

Table 10 Weighted-average Equipment Price, Installation Cost, and Total Installed Costs

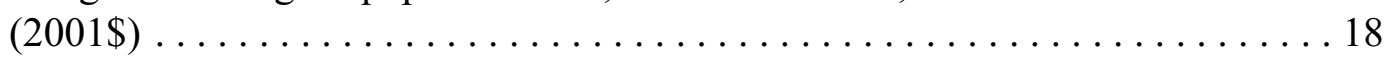

Table 11 Marginal Prices Computed from Air Conditioning Load Reductions Using the Tariff-based and Hourly-based Electricity Price Models . . . . . . . . . . . . . 23

Table 12

Table 13

Table 14

Table 15

Table 16

Table 17

Table 18

Weighted-average Annualized Repair Costs . . . . . . . . . . . . . . . 26

Annualized Maintenance Costs for Baseline Efficient Air Conditioners . . . . . 28

Average Values for Variables Used to Estimate Company Discount Rates . . . 31

Sectors that Purchase Commercial Air Conditioners . . . . . . . . . . . . . . 32

Description of Companies Included in Discount Rate Sample . . . . . . . . . 33

Real Discount Rates by Ownership Category . . . . . . . . . . . . . . . . 34

Sensitivity of Real Discount Rates to Equity Risk Premium and Risk Free Rate

Table 19 Baseline LCC: Tariff-Based Mean, Median, Minimum, and Maximum Values

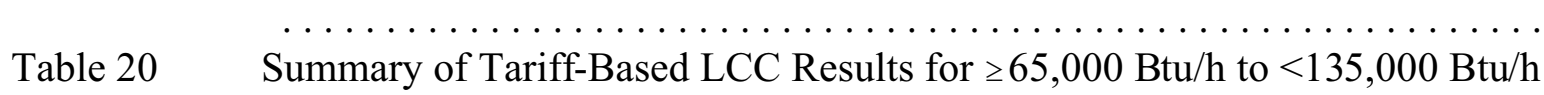

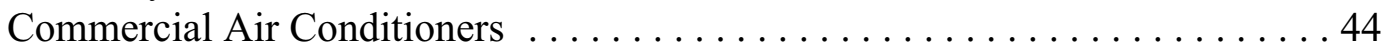

Table 21 Summary of Tariff-Based LCC Results for $\geq 135,000 \mathrm{Btu} / \mathrm{h}$ to $<240,000 \mathrm{Btu} / \mathrm{h}$

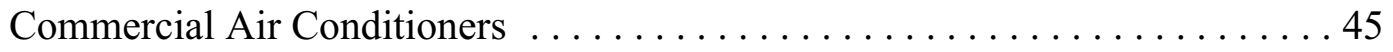

Table 22 Summary of Tariff-Based PBP Results for $\geq 65,000 \mathrm{Btu} / \mathrm{h}$ to $<135,000 \mathrm{Btu} / \mathrm{h}$

Commercial Air Conditioners . . . . . . . . . . . . . . . . 47

Table 23 Summary of Tariff-Based PBP Results for $\geq 135,000 \mathrm{Btu} / \mathrm{h}$ to $<240,000 \mathrm{Btu} / \mathrm{h}$

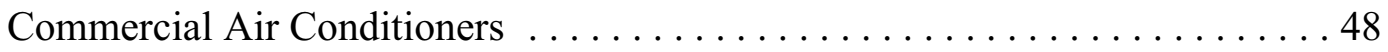

Table 24 Baseline LCC: Hourly-Based Mean, Median, Minimum, and Maximum Values

Table $25 \quad$ Summary of Hourly-Based LCC Results for $\geq 65,000 \mathrm{Btu} / \mathrm{h}$ to $<135,000 \mathrm{Btu} / \mathrm{h}$

Commercial Air Conditioners . . . . . . . . . . . . . . . . . 55

Table 26 Summary of Hourly-Based LCC Results for $\geq 135,000 \mathrm{Btu} / \mathrm{h}$ to $<240,000 \mathrm{Btu} / \mathrm{h}$

Commercial Air Conditioners . . . . . . . . . . . . . . . . . . 57

Table 27 Summary of Hourly-Based PBP Results for $\geq 65,000 \mathrm{Btu} / \mathrm{h}$ to $<135,000 \mathrm{Btu} / \mathrm{h}$

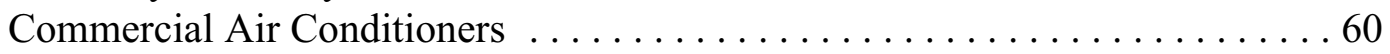


Table 28 Summary of Hourly-Based PBP Results for $\geq 135,000 \mathrm{Btu} / \mathrm{h}$ to $<240,000 \mathrm{Btu} / \mathrm{h}$

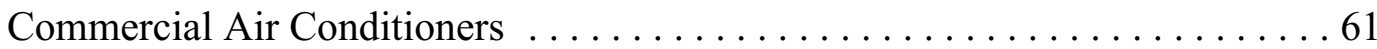

\section{LIST OF FIGURES}

Figure 1

Figure 2

Figure 3

Figure 4

Figure 5

Figure 6

Figure 7

Figure 8

Figure 9

Figure 10

Figure 11

Figure 12

Figure 13

Figure 14

Figure 15

Figure 16

Figure 17

Figure 18

Figure 19

Figure 20

Figure 21

Figure 22

Figure 23

Figure 27

Figure 28
Flow Diagram of Inputs for the Determination of LCC and PBP ......... 5

Air Conditioner Equipment (Operating) Weight as a Function of Efficiency . . 16

Electricity Price Trends for Commercial Rates ................. 25

Survival Functions for Commercial Air Conditioners and Residential Heat Pump 29

Distribution of Discount Rates for All Ownership Categories .......... . 35 $\geq 65,000 \mathrm{Btu} / \mathrm{h}$ to $<135,000 \mathrm{Btu} / \mathrm{h}$ : Mean Total Installed Costs . . . . . . 39

$\geq 135,000 \mathrm{Btu} / \mathrm{h}$ to $<240,000 \mathrm{Btu} / \mathrm{h}$ : Mean Total Installed Costs ...... . 39 $\geq 65,000 \mathrm{Btu} / \mathrm{h}$ to $<135,000 \mathrm{Btu} / \mathrm{h}$ : Tariff-Based Mean Annual

Operating Costs ............................... 39

$\geq 135,000 \mathrm{Btu} / \mathrm{h}$ to $<240,000 \mathrm{Btu} / \mathrm{h}$ : Tariff-Based Mean Annual Operating

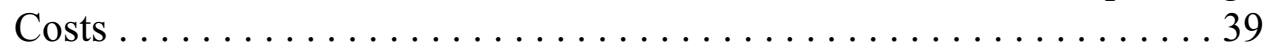

$\geq 65,000 \mathrm{Btu} / \mathrm{h}$ to $<135,000 \mathrm{Btu} / \mathrm{h}$ : Tariff-Based Mean Life-Cycle Costs . . . . . 39

$\geq 135,000 \mathrm{Btu} / \mathrm{h}$ to $<240,000 \mathrm{Btu} / \mathrm{h}$ : Tariff-Based Mean Life-Cycle Costs . . . . 39

$\geq 135,000 \mathrm{Btu} / \mathrm{h}$ to $<240,000 \mathrm{Btu} / \mathrm{h}$ : Tariff-Based Baseline (9.5 EER) LCC

Distribution ............................. 40

$\geq 65,000 \mathrm{Btu} / \mathrm{h}$ to $<135,000 \mathrm{Btu} / \mathrm{h}$ : Tariff-Based Baseline (10.1 EER) LCC

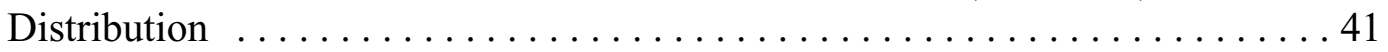

$\geq 65,000 \mathrm{Btu} / \mathrm{h}$ to $<135,000 \mathrm{Btu} / \mathrm{h}$ : Tariff-Based Cumulative Chart of LCC

Differences between 11.0 EER and Baseline (10.1 EER) ........... 43

$\geq 65,000 \mathrm{Btu} / \mathrm{h}$ to $<135,000 \mathrm{Btu} / \mathrm{h}$ : Tariff-Based Frequency Chart of LCC

Differences between 11.0 EER and Baseline (10.1 EER) ............ 43

$\geq 65,000 \mathrm{Btu} / \mathrm{h}$ to $<135,000 \mathrm{Btu} / \mathrm{h}$ : Tariff-Based Mean LCC Savings . . . . . . . 44

$\geq 65,000 \mathrm{Btu} / \mathrm{h}$ to $<135,000 \mathrm{Btu} / \mathrm{h}$ : Tariff-Based Percent of Units with LCC

Savings ................................ 44

$\geq 135,000 \mathrm{Btu} / \mathrm{h}$ to $<240,000 \mathrm{Btu} / \mathrm{h}$ : Tariff-Based Mean LCC Savings . . . . . . 45

$\geq 135,000 \mathrm{Btu} / \mathrm{h}$ to $<240,000 \mathrm{Btu} / \mathrm{h}$ : Tariff-Base Percent of Units with LCC

Savings ................................ 45

$\geq 65,000 \mathrm{Btu} / \mathrm{h}$ to $<135,000 \mathrm{Btu} / \mathrm{h}$ : Tariff-Based Frequency Chart of Payback

Periods for 11 EER .............................. 47

$\geq 65,000 \mathrm{Btu} / \mathrm{h}$ to $<135,000 \mathrm{Btu} / \mathrm{h}$ : Tariff-Based Mean and Median Payback

Periods ................................ 48

$\geq 135,000 \mathrm{Btu} / \mathrm{h}$ to $<240,000 \mathrm{Btu} / \mathrm{h}$ : Tariff-Based Mean and Median Payback

Periods .................................... 49

$\geq 65,000 \mathrm{Btu} / \mathrm{h}$ to $<135,000 \mathrm{Btu} / \mathrm{h}$ : Mean Total Installed Costs . ......... 52

$\geq 65,000 \mathrm{Btu} / \mathrm{h}$ to $<135,000 \mathrm{Btu} / \mathrm{h}$ : Hourly-Based Mean Life-Cycle Costs . . . . 52

$\geq 135,000 \mathrm{Btu} / \mathrm{h}$ to $<240,000 \mathrm{Btu} / \mathrm{h}$ : Hourly-Based Mean Life-Cycle Costs 
Figure $24 \geq 135,000 \mathrm{Btu} / \mathrm{h}$ to $<240,000 \mathrm{Btu} / \mathrm{h}$ : Mean Total Installed Costs . . . . . . . . 52

Figure $25 \geq 65,000 \mathrm{Btu} / \mathrm{h}$ to $<135,000 \mathrm{Btu} / \mathrm{h}$ : Hourly-Based Mean Annual

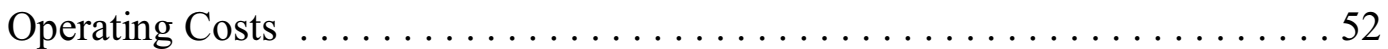

Figure $26 \geq 135,000 \mathrm{Btu} / \mathrm{h}$ to $<240,000 \mathrm{Btu} / \mathrm{h}$ : Hourly-Based Mean Annual

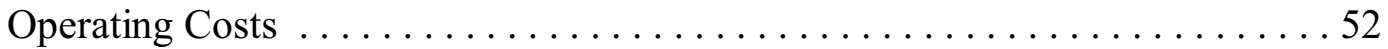

Figure $29 \geq 65,000 \mathrm{Btu} / \mathrm{h}$ to $<135,000 \mathrm{Btu} / \mathrm{h}$ : Hourly-Based Baseline (10.1 EER) LCC

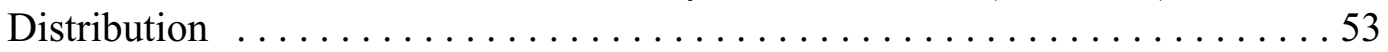

Figure $30 \geq 135,000 \mathrm{Btu} / \mathrm{h}$ to $<240,000 \mathrm{Btu} / \mathrm{h}$ : Hourly-Based Baseline (9.5 EER) LCC

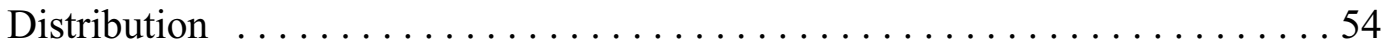

Figure 31 $\geq 65,000 \mathrm{Btu} / \mathrm{h}$ to $<135,000 \mathrm{Btu} / \mathrm{h}$ : Hourly-Based Mean LCC Savings . . . . . . 56

Figure 32 $\geq 65,000 \mathrm{Btu} / \mathrm{h}$ to $<135,000 \mathrm{Btu} / \mathrm{h}$ : Hourly-Based Percent of Units with LCC

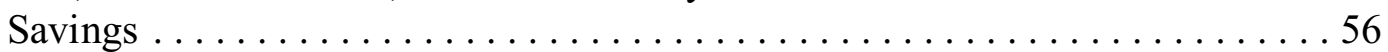

Figure $33 \geq 135,000 \mathrm{Btu} / \mathrm{h}$ to $<240,000 \mathrm{Btu} / \mathrm{h}$ : Hourly-Based Mean LCC Savings . . . . . 57

Figure $34 \geq 135,000 \mathrm{Btu} / \mathrm{h}$ to $<240,000 \mathrm{Btu} / \mathrm{h}$ : Hourly-Based Percent of Units with LCC

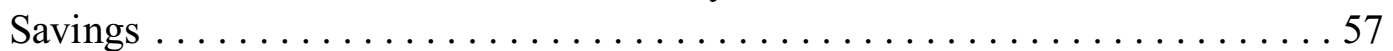

Figure $35 \geq 65,000 \mathrm{Btu} / \mathrm{h}$ to $<135,000 \mathrm{Btu} / \mathrm{h}$ : Hourly-Based Frequency Chart of Payback Periods for 11 EER . . . . . . . . . . . . . . . . . . . . . . . . 59

Figure $36 \geq 65,000 \mathrm{Btu} / \mathrm{h}$ to $<135,000 \mathrm{Btu} / \mathrm{h}$ : Hourly-Based Frequency Chart of Annual Energy Expense Differences between 11 EER and the Baseline (10.1 EER) . . 59

Figure $37 \geq 65,000 \mathrm{Btu} / \mathrm{h}$ to $<135,000 \mathrm{Btu} / \mathrm{h}$ : Hourly-Based Mean and Median Payback

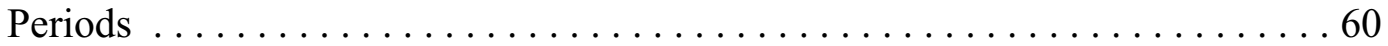

Figure $38 \geq 135,000 \mathrm{Btu} / \mathrm{h}$ to $<240,000 \mathrm{Btu} / \mathrm{h}$ : Hourly-Based Mean and Median Payback

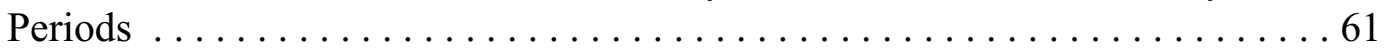




\section{$1 \quad$ INTRODUCTION}

The Energy Policy Act of 1992 (EPAct) amended the Energy Policy and Conservation Act of 1975 (EPCA) to include commercial unitary air conditioners and heat pumps in the Department of Energy's energy conservation program. EPCA, as amended by EPAct, established efficiency requirements that correspond to the levels in American Society of Heating, Refrigerating and Air-Conditioning Engineers, Inc. (ASHRAE)/Illuminating Engineering Society of North America (IESNA) Standard 90.1 as in effect on October 24, 1992. The statute further provides that if the efficiency levels in ASHRAE/IESNA Standard 90.1 are amended after that date for any of the covered products, including commercial unitary air conditioners and heat pumps, the Secretary of Energy (Secretary) must establish an amended uniform national standard for such equipment at the new minimum level for each effective date specified in ASHRAE/IESNA Standard 90.1, unless (s)he determines, through a rulemaking supported by clear and convincing evidence, that a more stringent standard is technologically feasible and economically justified and would result in significant additional energy conservation.

Under EPCA, if DOE adopts a more stringent standard, it must consider, to the greatest extent practicable, the economic impact of the standard on the manufacturers and consumers of the affected products; the savings in operating costs throughout the estimated average life of the product compared to any increases in the initial cost, or maintenance expense; the total projected amount of energy savings likely to result directly from the imposition of the standard; any lessening of the utility or the performance of the products likely to result from the imposition of the standard; the impact of any lessening of competition that is likely to result from the imposition of the standard; the need for national energy conservation; and other factors the Secretary considers relevant.

To address the above factors, DOE conducted an extensive analysis, as documented in the Technical Support Document (TSD). ${ }^{1}$ This report describes the analysis of the economic impacts of possible energy efficiency standards on consumers. It describes two metrics used to determine the effect of standards on individual consumers:

- Life-cycle cost (LCC) is the total customer expense over the life of an appliance, including purchase expense and operating costs (including energy expenditures). Future operating costs are discounted to the time of purchase, and summed over the lifetime of the equipment.

- $\quad$ Payback period (PBP) measures the amount of time it takes customers to recover the assumed higher purchase price of more energy-efficient equipment through lower operating costs.

Results for each metric are presented in Sections 4 and 5, respectively. The calculations discussed here were performed with a series of Microsoft Excel ${ }^{\circledR}$ spreadsheets which are accessible over the Internet 
(http://www.eere.energy.gov/buildings/appliance_standards/commercial/ac_hp.html).

\subsection{Technology Overview}

Unitary package air conditioning units represent the heating, ventilating, and air conditioning (HVAC) equipment class with the greatest energy use in the commercial sector in the United States. This equipment is used in 17.2 billion square feet of floor space, which is close to half of the cooled floor space in the commercial sector. It is responsible for annual energy use of about 0.74 quad of cooling and 0.44 quad of heating. ${ }^{2}$ Equipment covered under DOE's rulemaking accounts for the majority of the total shipped tonnage of unitary equipment for commercial building applications.

EPCA describes two specific categories of unitary package air conditioning units: small and large equipment. The small commercial package air conditioning and heating equipment category includes air cooled, water cooled, evaporatively cooled, or water source (not including ground water source), electrically operated, unitary central air conditioners and central air conditioning heat pumps for commercial application with less than 135,000 British thermal units per hour $(\mathrm{Btu} / \mathrm{h})$ cooling capacity. The large commercial package air conditioning and heating equipment category includes all the same items, rated at or above $135,000 \mathrm{Btu} / \mathrm{h}$ and below $240,000 \mathrm{Btu} / \mathrm{h}$ cooling capacity.

DOE's rulemaking is limited to air cooled package air conditioning and heating equipment rated at or greater than $65,000 \mathrm{Btu} / \mathrm{h}$, but less than $240,000 \mathrm{Btu} / \mathrm{h}$. It does not cover water cooled, evaporatively cooled, or water source equipment, nor does it cover equipment with cooling capacities of less than $65,000 \mathrm{Btu} / \mathrm{h}$. There are single package and split system air conditioners and heat pumps within the two categories defined above.

Single package air conditioning equipment houses all of the components - compressor, condenser and evaporator coils, expansion device, condenser and evaporator fans, and associated operating and control devices_-within a single cabinet. In most cases, this package unit is installed on the roof of a commercial building with supply and return air ducts for the building connected directly to the unit to provide conditioning for the building. In most installations, the manufacturer or the contractor in the field incorporates a heating section (typically gas-fired or electric resistance) within the equipment.

In a split system (also referred to as a remote condenser system), the compressor and the condenser coil and fan are together as the condensing unit in a cabinet located outside the building. Refrigerant piping connects the remote condensing unit to the separate indoor cabinet that contains the indoor fan and the evaporator coil and expansion device. 


\subsection{General Approach for LCC and PBP Analysis}

In recognition that each commercial building is unique, we analyzed variability and uncertainty by performing the LCC and PBP calculations detailed here for a representative sample of individual commercial buildings. Within a given building, one or more unitary airconditioning units can serve the building's space-conditioning needs, depending on the cooling load requirements of the building. We expressed the LCC and PBP results as the number of unitary air-conditioning units experiencing economic impacts from higher efficiency levels. The LCC and PBP model was developed using Microsoft Excel ${ }^{\circledR}$ spreadsheets combined with Crystal Ball $^{\circledR}$ (a commercially available add-in program).

The LCC and PBP analyses explicitly modeled both the uncertainty and the variability in the model's inputs using Monte Carlo simulation and probability distributions. The LCC and PBP results are displayed as distributions of impacts compared to the baseline conditions. Results presented in this report and are based on 10,000 samples per Monte Carlo simulation run.

\subsection{Overview of LCC and PBP Inputs}

Inputs to the LCC and PBP analysis are categorized as follows: 1) inputs for establishing the purchase expense, otherwise known as the total installed cost, and 2) inputs for calculating the operating expense.

The primary inputs for establishing the total installed cost are:

- $\quad$ Baseline manufacturer price: The price charged by the manufacturer to either a wholesaler or customer for equipment meeting existing minimum efficiency standards. The manufacturer price includes a markup that converts the cost to manufacture to a manufacturer price.

- $\quad$ Standard-level manufacturer price increases: The change in manufacturer price associated with producing equipment considered at each standard level.

- Markups and sales tax: The markups and sales tax associated with converting the manufacturer price to a customer price.

- Installation price: The cost to the customer of installing the equipment. The installation price represents all costs required to install the equipment other than the marked-up customer equipment price. The installation price includes labor, overhead, and any miscellaneous materials and parts.

The primary inputs for calculating the operating cost are:

- $\quad$ Equipment energy consumption and power demand: The equipment energy consumption is the site energy use associated with providing space-conditioning to the building. The 
power demand is the maximum power requirement of the equipment (more commonly known as the peak demand) for a specific period of time. Typically, electric utilities measure the peak demand for each month. Both the energy consumption and peak demand are calculated based on hourly whole-building simulations.

- $\quad$ Equipment efficiency: The energy efficiency ratio (EER) is the efficiency descriptor for commercial unitary air conditioners. The whole-building simulations assign specific baseline and standard level efficiencies to the unitary air-conditioning equipment to determine its corresponding energy consumption and peak demand.

- $\quad$ Electricity prices: The price per kWh paid by customers for electricity. Electricity prices are determined using two approaches: 1) a monthly approach based on the use of tariffs from a representative sample of electric utilities, and 2) an hourly approach based on the use of hourly wholesale electricity prices for those regions of the U.S. that are in deregulated electricity markets, and hourly system load and generation cost data for those regions of the U.S. that are in regulated electricity markets. The monthly approach calculates energy expenses based upon actual electricity prices which customers are currently paying. The hourly approach attempts to calculate energy expenses based upon electricity prices that customers may pay if electricity markets become deregulated.

- $\quad$ Electricity price trends: The Energy Information Administration's (EIA) Annual Energy Outlook 2003 (AEO2003) is used to forecast electricity prices into the future.

- $\quad$ Maintenance costs: The cost associated with maintaining the operation of the equipment.

- Repair costs: The cost associated with repairing or replacing components that have failed.

- Lifetime: The age at which the air-conditioning equipment is retired from service.

- Discount rate: The rate at which future expenditures are discounted to establish their present value.

Figure 1 graphically depicts the relationships between the installed cost and operating cost inputs for the calculation of the LCC and PBP. 


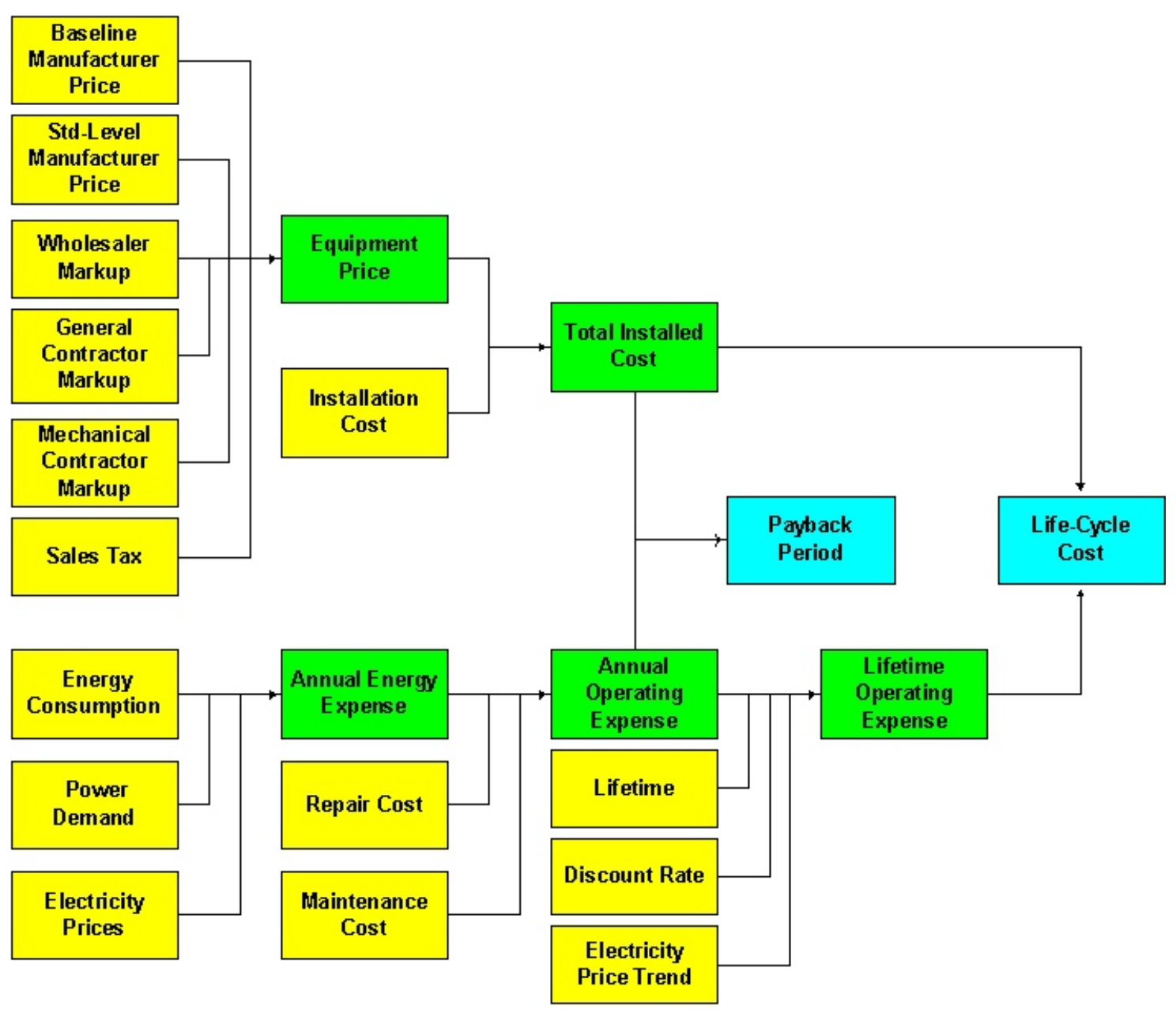

Figure 1 Flow Diagram of Inputs for the Determination of LCC and PBP

\subsection{Use of Whole-Building Simulations in LCC and PBP Analysis}

We conducted whole-building simulations on a representative sample of commercial buildings using commercial unitary air-conditioning equipment. Chapter 6 of the TSD, Building Energy Use and End-Use Load Characterization, describes the methods and assumptions used in the simulations.

The representative sample of buildings was drawn from the 1995 Commercial Building Energy Consumption Survey (CBECS). ${ }^{3}$ The 1995 CBECS includes 5,766 building records. The whole-building simulation analysis selected buildings that have at least 70 percent of their floor space conditioned by packaged air-conditioning equipment. Based on this criterion, the sample used in the whole-building simulation analysis consisted of 1,033 building records. 
The whole-building simulation analysis generates building energy consumption data for each hour of a typical meteorological year. For each of the 1,033 records in the building sample, the hourly building energy consumption is disaggregated into the air-conditioning energy consumption (i.e., the consumption due to the compressor and condenser fan), the supply or ventilation fan energy consumption, and the energy consumption due to all other electric enduses in the building. Because the supply fan is integral to the air-conditioning equipment, energy consumption for ventilation, even during periods where mechanical cooling is not required, is included as part of the total air-conditioning energy consumption.

The whole-building simulation data is coupled with electricity price data to generate an annual energy expense for air-conditioning for each of the 1,033 building records. We used two approaches to generate annual energy expense data: 1) a monthly approach, and 2) an hourly approach.

The monthly approach establishes an annual energy expense using electricity prices determined from electric utility tariffs collected in the year 2002. Under the monthly approach, we aggregated the hourly simulated energy consumption data into monthly energy consumption and peak demand values. We then coupled the monthly energy consumption and peak demand values with actual electric utility tariffs to calculate a monthly energy expense. We determined an annual energy expense by summing the monthly energy expenses.

The hourly approach establishes an annual energy expense using electricity prices that may exist assuming all electricity markets are deregulated. For electricity markets that are already deregulated, we collected actual wholesale hourly electricity prices. For markets that are still regulated, we collected hourly system load and generation cost data and then used these as a proxy for wholesale prices that may exist if the market were deregulated. Under the hourly approach, we coupled the hourly simulated energy consumption data directly with hourly electricity price data to calculate an annual energy expense.

Details on how we coupled the whole-building simulation data with both tariff-based and hourly-based electricity prices are given below.

\section{LIFE-CYCLE COST INPUTS}

\subsection{Definition}

Life-cycle cost (LCC) is the total customer expense over the life of an appliance, including purchase expense and operating costs (including energy expenditures). Future operating costs are discounted to the time of purchase, and summed over the lifetime of the equipment. Life-cycle cost is defined by the following equation:

$$
L C C=I C+\sum_{t=1}^{N} \frac{O C_{t}}{(1+r)^{t}}
$$


where
$L C C=\quad$ life-cycle cost,
$I C=\quad$ total installed cost $(\$)$,
$\sum=\quad$ sum over the lifetime, from year 1 to year $\mathrm{N}$, where $\mathrm{N}=$ lifetime of appliance (years),
$O C=\quad$ operating cost $(\$)$,
$r=\quad$ discount rate, and
$t=\quad$ year for which operating cost is being determined.

Throughout the LCC analysis, we expressed dollar values in 2001 dollars.

Total installed cost, operating cost, lifetime, and discount rate are discussed in the following sections.

\subsection{Total Installed Cost Inputs}

The total installed cost to the customer is defined by the following equation:

$$
I C=E Q P+I N S T
$$

where $E Q P$ is the equipment price, expressed in dollars, and INST is the installation cost or the customer price to install equipment, also in dollars.

The equipment price is based on how the customer purchases the equipment. We defined two types of distribution channels to describe how the equipment passes from the manufacturer to the customer in the first distribution channel, the manufacturer sells the equipment to a wholesaler, who in turn sells it to a general contractor, who in turn sells it to a mechanical contractor, who in turns sells it to the customer in the second distribution channel, the manufacturer sells the equipment directly to the customer through a national account. The first distribution channel is sub-divided into two types based on the size of the mechanical contractor (measured in annual revenues): 1) small mechanical contractors (those earning annual revenues of \$2 million and less) and 2) large mechanical contractors (those earning annual revenues over \$2 million).

\subsubsection{Baseline Manufacturer Price}

The baseline manufacturer price is the price charged by manufacturers to either a wholesaler or customer for equipment meeting existing minimum efficiency standards. The manufacturer price includes a markup that converts the cost to manufacture to a manufacturer price.

We used the baseline manufacturer prices that were developed by DOE through an efficiency level analysis approach. Refer to Chapter 5 of the TSD, the Engineering Analysis, for details. Manufacturer prices were developed for two cooling capacity sizes of commercial air 
conditioners: 1) a 7.5-ton $(90,000 \mathrm{Btu} / \mathrm{h})$ single package air conditioner representative of the $\geq$ $65,000 \mathrm{Btu} / \mathrm{h}$ to $<135,000 \mathrm{Btu} / \mathrm{h}$ single package and split system unitary air conditioner equipment class, and 2) a 15-ton $(180,000 \mathrm{Btu} / \mathrm{h})$ single package air conditioner representative of the $\geq 135,000 \mathrm{Btu} / \mathrm{h}$ to $<240,000 \mathrm{Btu} / \mathrm{h}$ single package and split system unitary air conditioner equipment class. DOE did not develop manufacturer prices for either of the heat pump equipment classes.

EPCA requires DOE to establish an amended uniform national standard for commercial unitary air conditioners and heat pumps at the minimum level specified in American Society of Heating, Refrigeration, and Air-Conditioning Engineers (ASHRAE)/Illuminating Engineering Society of North America (IESNA) Standard 90.1-1999, unless DOE determines that a more stringent standard is technologically feasible and economically justified and would result in significant additional energy conservation. Because it was not able to consider levels lower than that of the most recent ASHRAE/IESNA Standard 90.1, DOE considered the baseline efficiency to be the minimum level specified in ASHRAE/IESNA Standard 90.1-1999. Table 1 presents the ASHRAE/IESNA Standard 90.1-1999 minimum space-cooling efficiency levels for the two commercial unitary air conditioner equipment classes being analyzed. 
Table 1 ASHRAE/IESNA Standard 90.1-1999 Minimum EER Requirements for Commercial Unitary Air Conditioners

\begin{tabular}{c|c|c|c}
\hline Size Category & Heating Section Type & Sub-Category & $\begin{array}{c}\text { Minimum } \\
\text { Efficiency }\end{array}$ \\
\hline $\begin{array}{c}\geq 65,000 \mathrm{~B} \text { tu/h to } \\
<135,000 \mathrm{Btu} / \mathrm{h}\end{array}$ & Electric Resistance (or None) & Split System and Single Package & $10.3 \mathrm{EER}$ \\
& All Other & Split System and Single Package & $10.1 \mathrm{EER}$ \\
\hline $\begin{array}{c}2135,000 \mathrm{Btu} / \mathrm{h} \text { to } \\
<240,000 \mathrm{Btu} / \mathrm{h}\end{array}$ & Electric Resistance (or None) & Split System and Single Package & $9.7 \mathrm{EER}$ \\
& All Other & Split System and Single Package & $9.5 \mathrm{EER}$ \\
\hline
\end{tabular}

Because we estimated that a significant portion of the single package air conditioning market has gas-heating as compared to either air conditioning only or electric resistance heating, the baseline efficiency levels are based on equipment with a gas heating section (i.e., 10.1 EER for the $\geq 65,000$ to $135,000 \mathrm{Btu} / \mathrm{h}$ equipment class and 9.5 EER for the $\geq 135,000$ to 240,000 $\mathrm{Btu} / \mathrm{h}$ class). Table 2 summarizes the manufacturer prices for baseline commercial air conditioners.

Table 2 Baseline Manufacturer Prices

\begin{tabular}{|c|c|c|}
\hline System Type & $\begin{array}{l}\text { Baseline } \\
\text { Efficiency }\end{array}$ & $\begin{array}{c}\text { Baseline Manufacturer } \\
\text { Price (2001\$) }\end{array}$ \\
\hline $\begin{array}{l}\geq 65,000 \mathrm{Btu} / \mathrm{h} \text { to }<135,000 \mathrm{Btu} / \mathrm{h} \text { Single Package and } \\
\text { Split System Unitary Air Conditioners }\end{array}$ & 10.1 EER & $\$ 2,098$ \\
\hline $\begin{array}{l}\geq 135,000 \mathrm{Btu} / \mathrm{h} \text { to }<240,000 \mathrm{Btu} / \mathrm{h} \text { Single Package } \\
\text { and Split System Unitary Air Conditioners }\end{array}$ & 9.5 EER & $\$ 3,957$ \\
\hline
\end{tabular}

\subsubsection{Standard-level Manufacturer Price Increases}

The standard-level manufacturer price increase is the change in manufacturer price associated with producing equipment at higher standard levels. DOE developed manufacturer price increases associated with increases in equipment standard levels through an efficiency level analysis approach. Manufacturer price increases as a function of equipment efficiency (i.e., EER) were developed for each of the two cooling capacity sizes of commercial air conditioners.

Although DOE expressed the manufacturer price increases as a continuous function of efficiency, we only carried forward and analyzed specific efficiency levels in the LCC and PBP analysis. Table 3 lists the efficiency levels considered for the $\geq 65,000 \mathrm{Btu} / \mathrm{h}$ to $<135,000 \mathrm{Btu} / \mathrm{h}$ equipment class, and for the $\geq 135,000 \mathrm{Btu} / \mathrm{h}$ to $<240,000 \mathrm{Btu} / \mathrm{h}$ equipment class.

The efficiency level analysis established a distribution of manufacturer price increases for each standard level. Upper and lower bounds were established for each standard level at 95 
percent confidence intervals assuming a normal distribution. Table 3 summarizes the minimum, average, and maximum manufacturer price increases for the commercial air conditioner standard levels considered in the analysis.

Table 3 Standard-level Manufacturer Price Increases

\begin{tabular}{|c|c|c|c|c|c|c|}
\hline \multirow[b]{3}{*}{ EER } & \multicolumn{6}{|c|}{ Standard-Level Manufacture Price Increase (2001\$) } \\
\hline & \multicolumn{3}{|c|}{$\begin{array}{c}\geq 65,000 \mathrm{Btu} / \mathrm{h} \text { to }<135,000 \mathrm{Btu} / \mathrm{h} \\
\text { Unitary Air Conditioners }\end{array}$} & \multicolumn{3}{|c|}{$\begin{array}{c}\geq 135,000 \mathrm{Btu} / \mathrm{h} \text { to }<240,000 \mathrm{Btu} / \mathrm{h} \\
\text { Unitary Air Conditioners }\end{array}$} \\
\hline & Min* & Mean & Max* & Min* & Mean & Max* \\
\hline 10.0 & - & - & - & $\$ 27$ & $\$ 62$ & $\$ 98$ \\
\hline 10.5 & $\$ 33$ & $\$ 47$ & $\$ 61$ & $\$ 70$ & $\$ 165$ & $\$ 259$ \\
\hline 11.0 & $\$ 98$ & $\$ 139$ & $\$ 180$ & $\$ 142$ & $\$ 334$ & $\$ 525$ \\
\hline 11.5 & $\$ 206$ & $\$ 292$ & $\$ 377$ & $\$ 261$ & $\$ 613$ & $\$ 964$ \\
\hline 12.0 & $\$ 383$ & $\$ 543$ & $\$ 702$ & $\$ 457$ & $\$ 1,072$ & $\$ 1,687$ \\
\hline
\end{tabular}

* Minimum and maximum values are actually the upper and lower bounds at the 95 percent confidence interval of a normal distribution.

\subsubsection{Overall Markup}

For a given distribution channel, the overall markup is the value determined from multiplying all the associated markups and sales tax together to arrive at a single markup value. The overall markup is multiplied by the baseline or standard-level manufacturer price to arrive at the price paid by the customer. The overall markup is divided into a baseline markup (i.e., a markup used to convert the baseline manufacturer price into a customer price) and an incremental markup (i.e., a markup used to convert an incremental manufacturer price due to an efficiency increase into an incremental customer price).

As discussed in Chapter 7 of the TSD, overall markups are based on one of three assumed distribution channels as well as on whether the equipment is being purchased for the new construction or replacement market. The distribution channel is based on whether equipment is purchased through: 1) small mechanical contractors, 2) large mechanical contractors, or 3) national accounts.

Based on input from equipment manufacturers, the new construction and replacement markets represent 30 and 70 percent of the market, respectively. With regard to the distribution channels, based on input from equipment manufacturers, 50 percent of equipment purchased by end-use customers are through small mechanical contractors, 32.5 percent are through large mechanical contractors, and the remaining 17.5 percent are through national accounts. With two different markets and three different distribution channels, there are a total of six overall baseline and incremental markups possible. All six sets of overall markups and their associated components are presented in Tables 4 and 5 for the baseline and incremental markups, respectively. Based on the percentages of the market attributed to new construction and replacements and the percentages attributed to each of the three distribution channels, weighted- 
average overall markups are also presented. The weighted-average overall baseline markup equals 2.31, while the weighted-average overall incremental markup equals 1.56.

Table 4 Overall Baseline Markups

\begin{tabular}{|c|c|c|c|c|c|c|c|}
\hline \multirow[b]{2}{*}{ Market Sector } & \multicolumn{3}{|c|}{ New Construction } & \multicolumn{3}{|c|}{ Replacement } & \multirow{2}{*}{$\begin{array}{l}\text { Weighted- } \\
\text { Average }\end{array}$} \\
\hline & $\begin{array}{l}\text { Small } \\
\text { Mech. }\end{array}$ & $\begin{array}{l}\text { Large } \\
\text { Mech. }\end{array}$ & $\begin{array}{l}\text { National } \\
\text { Account }\end{array}$ & $\begin{array}{l}\text { Small } \\
\text { Mech. }\end{array}$ & $\begin{array}{l}\text { Large } \\
\text { Mech. }\end{array}$ & $\begin{array}{l}\text { National } \\
\text { Account }\end{array}$ & \\
\hline Wholesale & 1.36 & 1.36 & & 1.36 & 1.36 & & \\
\hline Mechanical Contractor & 1.48 & 1.35 & 1.69 & 1.70 & 1.55 & 1.60 & \\
\hline General Contractor & 1.24 & 1.24 & & NA & NA & & \\
\hline Sales Tax & 1.07 & 1.07 & 1.07 & 1.07 & 1.07 & 1.07 & \\
\hline Overall & 2.66 & 2.42 & 1.80 & 2.47 & 2.24 & 1.71 & 2.31 \\
\hline
\end{tabular}

Table 5 Overall Incremental Markups

\begin{tabular}{|c|c|c|c|c|c|c|c|}
\hline \multirow[b]{2}{*}{ Market Sector } & \multicolumn{3}{|c|}{ New Construction } & \multicolumn{3}{|c|}{ Replacement } & \multirow{2}{*}{$\begin{array}{c}\text { Weighted- } \\
\text { Average }\end{array}$} \\
\hline & $\begin{array}{l}\text { Small } \\
\text { Mech. }\end{array}$ & $\begin{array}{l}\text { Large } \\
\text { Mech. }\end{array}$ & $\begin{array}{l}\text { National } \\
\text { Account }\end{array}$ & $\begin{array}{l}\text { Small } \\
\text { Mech. }\end{array}$ & $\begin{array}{l}\text { Large } \\
\text { Mech. }\end{array}$ & $\begin{array}{l}\text { National } \\
\text { Account }\end{array}$ & \\
\hline Wholesale & 1.11 & 1.11 & & 1.11 & 1.11 & & \\
\hline Mechanical Contractor & 1.26 & 1.18 & 1.27 & 1.37 & 1.29 & 1.24 & \\
\hline General Contractor & 1.13 & 1.13 & & NA & NA & & \\
\hline Sales Tax & 1.07 & 1.07 & 1.07 & 1.07 & 1.07 & 1.07 & \\
\hline Overall & 1.69 & 1.59 & 1.35 & 1.63 & 1.53 & 1.32 & 1.56 \\
\hline
\end{tabular}

\subsubsection{Installation Cost}

The installation cost is the price to the customer of labor and materials needed to install air-conditioning equipment. We derived installation costs for commercial air conditioners from data in RS Means Mechanical Cost Data, 2002. ${ }^{4}$ This book provides estimates on the personhours required to install commercial air-conditioning equipment and the labor rates associated with the type of crew required to install the equipment. The installation cost was calculated by multiplying the number of person-hours by the corresponding labor rate. RS Means provides specific person-hour and labor rate data for the installation of 7.5-ton and 15-ton roof top air conditioners. We decided that 7.5-ton and 15-ton roof top air conditioner data are representative of installation costs for the $\geq 65,000 \mathrm{Btu} / \mathrm{h}$ to $<135,000 \mathrm{Btu} / \mathrm{h}$ to the $\geq 135,000 \mathrm{Btu} / \mathrm{h}$ to $<$ $240,000 \mathrm{Btu} / \mathrm{h}$ air conditioner equipment classes, respectively.

Labor rates vary significantly by region of the country and the $R S$ Means data provides the necessary information to capture this regional variability. Cost indices to vary the labor rate for several cities from around the United States. Several cities in all 50 states of the United States and the District of Columbia are identified in the RS Means data and were incorporated 
into the analysis to vary the installation cost depending on the location of the customer.

Since data were not available to indicate how installation costs vary with equipment efficiency, we considered two scenarios: 1) installation costs vary in direct proportion with the weight of the equipment and 2) installation costs do not vary with equipment weight. For the former case, we developed linear relationships of operating weight as a function of equipment efficiency for 7.5-ton and 15-ton commercial air conditioners. Thus, under this scenario, installation costs vary linearly with equipment efficiency. To be conservative, the default installation cost scenario in the LCC and PBP analyses uses installation costs that vary with equipment weight. The spreadsheets are also able to calculate LCC and PBP based on the constant installation cost scenario.

Table 6 summarizes the nationally representative person-hours and labor rates associated with the installation of 7.5-ton and 15-ton roof top air conditioners. Both bare installation costs (i.e., costs before overhead and profit (O\&P)) and installation costs including O\&P are provided. We decided that the 7.5-ton and 15-ton installation costs that include O\&P represent the installation costs for baseline efficient systems.

Table 6 Installation Costs for Baseline Air Conditioners

\begin{tabular}{l|c|cc|cc}
\hline & & \multicolumn{2}{|c|}{$\mathbf{2 0 0 2}$ Base Costs (2001\$) } & \multicolumn{2}{c}{ Labor w/ O\&P (2001\$) } \\
\cline { 3 - 6 } System Type* & $\begin{array}{c}\text { Person- } \\
\text { hours }\end{array}$ & $\begin{array}{c}\text { Cost per } \\
\text { Person-hour }\end{array}$ & $\begin{array}{c}\text { Total Labor } \\
\text { Cost }\end{array}$ & $\begin{array}{c}\text { Cost per } \\
\text { Person-hour }\end{array}$ & $\begin{array}{c}\text { Total Labor } \\
\text { Cost }\end{array}$ \\
\hline 7.5-ton cooling, $170 \mathrm{kBtu} / \mathrm{h}$ heating & 32.26 & $\$ 32.58$ & $\$ 1,051$ & $\$ 49.13$ & $\$ 1,585$ \\
15 -ton cooling, 270 kBtu/h heating & 42.03 & $\$ 33.78$ & $\$ 1,420$ & $\$ 50.95$ & $\$ 2,142$ \\
\hline
\end{tabular}

* Description as in RS Means for roof top air conditioners with standard controls, curb, economizer, and a single-zone, electric cooling, gas heating unit.

Table 7 summarizes the cost indices used to vary the nationally representative installation costs for installations in each of the 50 states of the U.S. plus the District of Columbia. RS Means Mechanical Cost Data provides indices for 295 cities from around the U.S. To arrive at an average index for each state, the city indices in each state were weighted by their population. Population estimates for the year 1999 from the U.S. Census Bureau were used to calculate a weighted-average index for each state.

Table $7 \quad$ Installation Cost Indices (National Value $=\mathbf{1 0 0 . 0}$ )

\begin{tabular}{lc||lc||lc}
\hline State & Index & State & Index & State & Index \\
\hline Alabama & 57.7 & Kentucky & 70.4 & North Dakota & 66.2 \\
Alaska & 109.0 & Louisiana & 58.2 & Ohio & 100.1 \\
Arizona & 79.0 & Maine & 80.2 & Oklahoma & 64.7 \\
Arkansas & 53.2 & Maryland & 83.4 & Oregon & 111.4 \\
California & 120.7 & Massachusetts & 111.0 & Pennsylvania & 114.5 \\
Colorado & 80.7 & Michigan & 104.7 & Rhode Island & 102.6
\end{tabular}




\begin{tabular}{|c|c|c|c|c|c|}
\hline Connecticut & 104.5 & Minnesota & 109.8 & South Carolina & 44.7 \\
\hline D.C. & 89.8 & Mississippi & 44.6 & South Dakota & 39.3 \\
\hline Delaware & 108.0 & Missouri & 96.9 & Tennessee & 65.9 \\
\hline Florida & 59.1 & Montana & 78.9 & Texas & 65.5 \\
\hline Georgia & 59.2 & Nebraska & 84.5 & Utah & 72.0 \\
\hline Hawaii & 124.8 & Nevada & 105.5 & Vermont & 72.0 \\
\hline Idaho & 78.5 & New Hampshire & 90.9 & Virginia & 68.5 \\
\hline Illinois & 118.3 & New Jersey & 120.8 & Washington & 104.0 \\
\hline Indiana & 89.7 & New Mexico & 74.9 & West Virginia & 88.2 \\
\hline Iowa & 82.7 & New York & 155.3 & Wisconsin & 96.3 \\
\hline Kansas & 74.4 & North Carolina & 48.2 & Wyoming & 54.5 \\
\hline
\end{tabular}

Figure 2 shows the relationship between equipment weight (otherwise known as operating weight) and efficiency for 7.5-ton and 15-ton air conditioners. ${ }^{\text {a }}$ Each point in the figure represents an actual model available. A least-squares linear fit was developed to relate equipment weight to efficiency (the equations relating equipment weight to efficiency are shown in the figure). The weight tends to increase with efficiency more for the larger units.

a The data in Figure 2 were developed by DOE, as described in Chapter X of the TSD. 


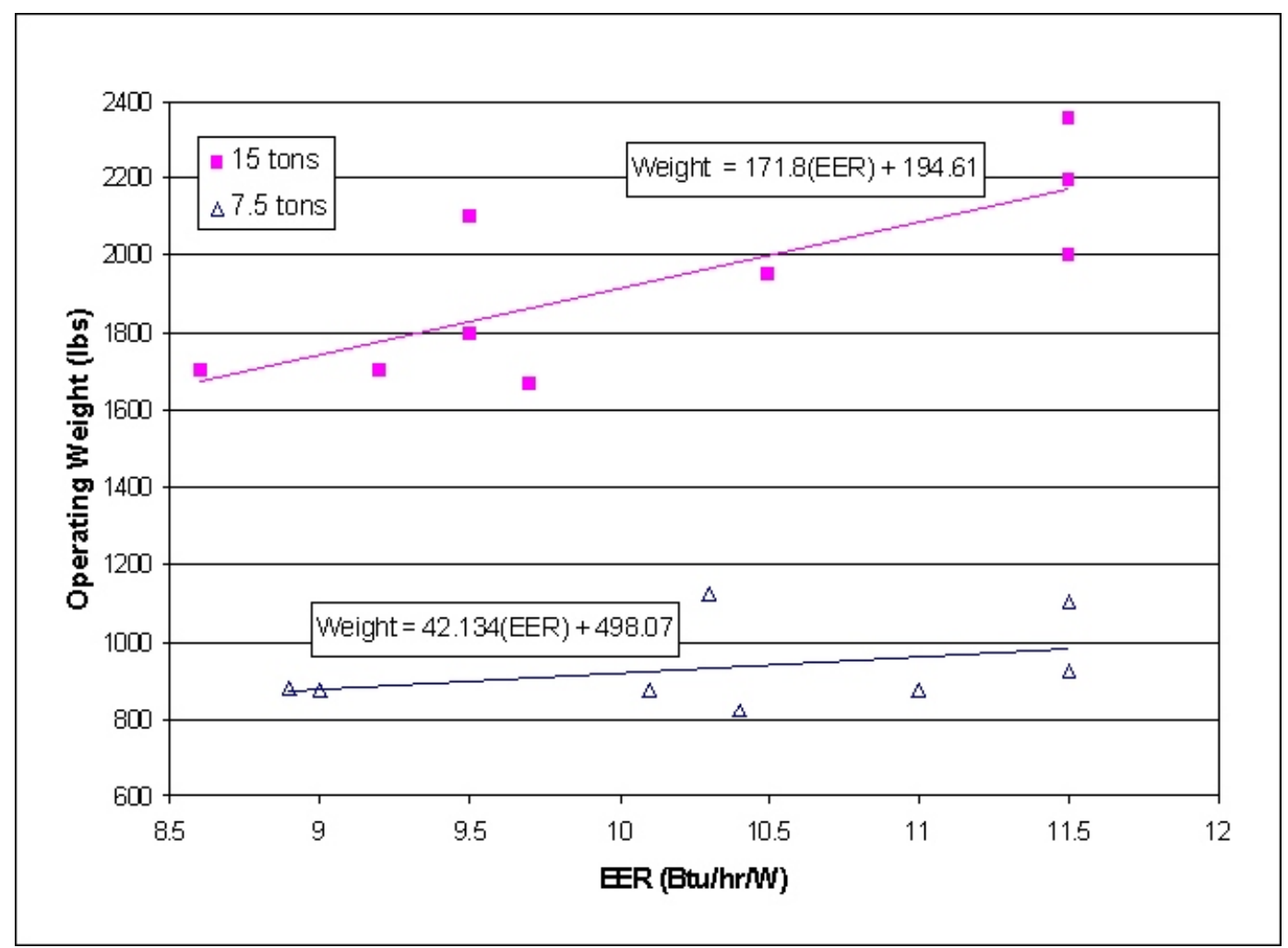

Figure 2 Air Conditioner Equipment (Operating) Weight as a Function of Efficiency

\subsubsection{Weighted-average Total Installed Cost}

The total installed cost is the sum of the equipment price and the installation cost. DOE derived the customer equipment price for any given standard level by multiplying the baseline manufacturer price by the baseline markup and adding to it the product of the incremental manufacturer price and the incremental markup.

The baseline manufacturer price and the standard-level manufacturer price increases are the starting points for determining the total installed cost. The baseline and incremental markups, the sales tax, and installation costs are used to convert the manufacturer prices into 
total installed costs. Table 8 summarizes all of the weighted-average or mean costs and markups necessary for determining the weighted-average baseline and standard-level total installed costs.

Table 8 Costs and Markups for Determination of Weighted-Average Total Installed

\begin{tabular}{|c|c|}
\hline Variable & Weighted-Average or Mean Value \\
\hline Baseline Manufacturer Price & $\begin{array}{l}\geq 65,000 \mathrm{Btu} / \mathrm{h} \text { to }<135,000 \mathrm{Btu} / \mathrm{h} \text { Unitary Air Conditioners }=\$ 2098 ; \\
\geq 135,000 \mathrm{Btu} / \mathrm{h} \text { to }<240,000 \mathrm{Btu} / \mathrm{h} \text { Unitary Air Conditioners }=\$ 3957\end{array}$ \\
\hline Std-Level Manuf. Price Increase & Refer to Mean Values in Table 3 for each equipment class \\
\hline Overall Markup - Baseline & 2.32 \\
\hline Overall Markup - Incremental & 1.56 \\
\hline Installation Cost - Baseline & $\begin{array}{l}\geq 65,000 \mathrm{Btu} / \mathrm{h} \text { to }<135,000 \mathrm{Btu} / \mathrm{h} \text { Unitary Air Conditioners }=\$ 1585 ; \\
\geq 135,000 \mathrm{Btu} / \mathrm{h} \text { to }<240,000 \mathrm{Btu} / \mathrm{h} \text { Unitary Air Conditioners }=\$ 2142\end{array}$ \\
\hline Installation Cost - Incremental & Increases in direct proportion to equipment weight \\
\hline
\end{tabular}

To illustrate the derivation of the weighted-average total installed cost, we present the calculation below for a baseline (i.e., 10.1 EER) and 11 EER air conditioner for the $\geq 65,000$ $\mathrm{Btu} / \mathrm{h}$ to $<135,000 \mathrm{Btu} / \mathrm{h}$ equipment class. For baseline $\geq 65,000 \mathrm{Btu} / \mathrm{h}$ to $<135,000 \mathrm{Btu} / \mathrm{h}$ unitary air conditioners, the calculation of the total installed cost $\left(I C_{\text {Base 65-135 }}\right)$ is as follows:

$$
\begin{aligned}
I C_{\text {BASE } 65-135} & =E Q P_{\text {BASE } 65-135}+I N S T_{\text {BASE } 65-135} \\
& =M F G_{\text {BASE } 65-135} \cdot M U_{\text {BASE OVERALL }}+I N S T_{\text {BASE } 65-135} \\
& =\$ 2098 \cdot 2.31+\$ 1585 \\
& =\$ 4855+\$ 1585 \\
& =\$ 6440
\end{aligned}
$$

where $M F G$ is the manufacturer price, expressed in dollars, and $M U$ is the markup. In this specific example, $M F G$ is the baseline manufacturer price for the $\geq 65,000 \mathrm{Btu} / \mathrm{h}$ to $<135,000$ $\mathrm{Btu} / \mathrm{h}$ equipment class and $M U$ is the overall baseline markup.

The calculation of the 11 EER air conditioner total installed cost includes the use of a manufacturer price adder. In addition, since we derived an incremental markup based on incremental equipment price changes, the derivation of the 11 EER total installed cost is based on determining the change in equipment price over the baseline equipment price. Also note that since the installation cost scales with the equipment weight, the ratio of the 11 EER to the baseline (10.1 EER) equipment is used to increase the installation cost for the 11 EER unit. Refer back to Figure 2 for the equation used to calculate equipment weight as a function of EER. DOE calculated the 11 EER total installed cost $\left(I C_{11 \text { EER 65-135 }}\right)$ as follows: 


$$
\begin{aligned}
I C_{11 \text { EER } 65-135}= & E Q P_{\text {BASE } 65-135}+\Delta E Q P_{11 \text { EER } 65-135}+I N S T_{\text {BASE } 65-135} \cdot\left(\frac{\text { eight }_{11 \text { EER } 65-135}}{\text { Weight }_{\text {BASE } 65-135}}\right) \\
= & M F G_{\text {BASE 65-135 }} \cdot M U_{\text {BASE OVERALL }}+\Delta M F G_{11 \text { EER } 65-135} \cdot M U_{\text {INCR OVERALL }} \\
& +N S T_{\text {BASE } 65-135} \cdot\left(\frac{42.134 \cdot 11 \text { EER }+498.07}{42.134 \cdot 10.1 E E R+498.07}\right) \\
= & \$ 2098 \cdot 2.31+(\$ 139 \cdot 1.56)+\$ 1586 \cdot\left(\frac{962 l b}{924 l b}\right) \\
= & \$ 4855+\$ 217+\$ 1650 \\
= & \$ 6722
\end{aligned}
$$

Table 9 presents the weighted-average equipment price, installation costs, and total installed costs for the two air conditioner equipment classes at the baseline level and each standard-level.

Table 9 Weighted-average Equipment Price, Installation Cost, and Total Installed Costs (2001\$)

\begin{tabular}{c|c|c|c|c|c|c}
\hline \multirow{2}{*}{ EER } & \multicolumn{2}{|c|}{$\begin{array}{c}\mathbf{6 5 , 0 0 0} \text { and }<\mathbf{1 3 5 , 0 0 0} \mathbf{B t u} / \mathbf{h} \\
\text { Unitary Air Conditioners }\end{array}$} & \multicolumn{3}{|c|}{$\begin{array}{c}\mathbf{1 3 5 , 0 0 0} \text { and }<240,000 \mathrm{Btu} / \mathbf{h} \\
\text { Unitary Air Conditioners }\end{array}$} \\
\cline { 2 - 7 } & $\begin{array}{c}\text { Equipment } \\
\text { Price }\end{array}$ & $\begin{array}{c}\text { Installation } \\
\text { Cost }\end{array}$ & $\begin{array}{c}\text { Total Installed } \\
\text { Cost }\end{array}$ & $\begin{array}{c}\text { Equipment } \\
\text { Price }\end{array}$ & $\begin{array}{c}\text { Installation } \\
\text { Cost }\end{array}$ & $\begin{array}{c}\text { Total Installed } \\
\text { Cost }\end{array}$ \\
\hline $9.5^{\mathrm{a}}$ & - & - & - & $\$ 9,157$ & $\$ 2,142$ & $\$ 11,299$ \\
10.0 & - & - & - & $\$ 9,254$ & $\$ 2,243$ & $\$ 11,497$ \\
$10.1^{\mathrm{b}}$ & $\$ 4,855$ & $\$ 1,585$ & $\$ 6,440$ & - & - & - \\
10.5 & $\$ 4,928$ & $\$ 1,614$ & $\$ 6,542$ & $\$ 9,414$ & $\$ 2,343$ & $\$ 11,757$ \\
11.0 & $\$ 5,072$ & $\$ 1,650$ & $\$ 6,722$ & $\$ 9,677$ & $\$ 2,444$ & $\$ 12,121$ \\
11.5 & $\$ 5,309$ & $\$ 1,686$ & $\$ 6,995$ & $\$ 10,111$ & $\$ 2,545$ & $\$ 12,656$ \\
12.0 & $\$ 5,700$ & $\$ 1,722$ & $\$ 7,422$ & $\$ 10,826$ & $\$ 2,646$ & $\$ 13,472$ \\
\hline
\end{tabular}

a $9.5 \mathrm{EER}$ is baseline efficiency for the $\geq 135,000 \mathrm{Btu} / \mathrm{h}$ to $<240,000 \mathrm{Btu} / \mathrm{h}$ equipment class

${ }^{\mathrm{b}} 10.1 \mathrm{EER}$ is baseline efficiency for the $\geq 65,000 \mathrm{Btu} / \mathrm{h}$ to $<135,000 \mathrm{Btu} / \mathrm{h}$ equipment class

\subsection{Operating Cost Inputs}

We based the operating cost for the LCC analysis on energy consumption data developed from whole-building simulations on a sample of building from the 1995 Commercial Building Energy Consumption Survey (CBECS). After the LCC analysis was performed, we generated a distribution of LCC differences (i.e., the LCC difference between the baseline equipment and equipment with a higher efficiency level) to determine the mean LCC difference, as well as the percentage of buildings analyzed that had LCC savings associated with more efficient equipment. 
We defined the operating cost by the following equation:

$$
O C=E C+R C+M C
$$

where $E C$ is energy expenditure associated with operating the equipment, $R C$ is the repair cost associated with component failure, and $M C$ is the service cost for maintaining equipment operation.

\subsubsection{Electricity Price Analysis}

This section describes the electricity price analyses used to develop the energy portion of the annual operating expenses for central air conditioning in the commercial sector. For a more detailed discussion, see Chapter 8 of the TSD.

The electric power industry is currently in a state of transition between two different business models, from regulated monopoly utilities providing bundled service to all customers in their service area, to a system of deregulated independent suppliers who compete for customers. While it is unclear when this transition will be completed, it is possible that in the near future customers will see a very different pricing structure for electricity. To account for the impacts of this change on the LCC, we used two different electricity price models in this analysis. The first uses information on utility tariffs for commercial customers collected in 2001 from a sample of 90 utilities across the country. The second is based on electricity production prices that vary on an hourly basis, and is used to model a scenario in which customers are charged directly for the costs incurred to the electricity provider in supplying the air conditioning end-use. We refer to the two analyses as "tariff-based" and "hourly-based," respectively.

To account for the wide regional variation in electricity usage patterns, wholesale costs, and retail rates across the country, we divided the continental U.S. into 17 subdivisions. The breakdown started with the nine census divisions, which were further subdivided to take into account significant climate variation and the existence of different electricity market or grid structures. We based climate divisions on the nine climate regions defined for the continental U.S. by the National Climatic Data Center. We separated out Texas, Florida, New York, and California because their electric grids operate independently. Finally, we assigned each record from the 1033 building sample to one of the 17 subdivisions and both the tariff-based and hourlybased approaches used the complete set of 1033 buildings to develop electricity prices.

\section{(a) Tariff-Based Approach}

The tariff-based approach uses tariffs for commercial customers collected for a sample of 90 utilities across the country. We used three main criteria in developing the utility sample: (1) the sample of utilities should reflect the distribution of population across the country, with more utilities drawn from more populated areas; (2) the sample should reflect the proportion of customers served by privately-owned (investor-owned utilities and power marketers) versus 
publicly-owned utilities (municipals, cooperatives, State, and Federal); and (3) the sample should cover as many customers as possible. We used data from DOE's Energy Information Administration (EIA) Form 861 filings for the year 2000 to determine the number of customers served by utilities of different types. We determined the representativeness of the sample by the percentage of the total number of commercial and industrial (C\&I) customers who were covered. The sampled utilities serve 60 percent of the C\&I customers of private utilities, and 14.4 percent of C\&I customers for public utilities. The combined total for the U.S. is 48.5 percent of all C\&I customers.

We collected tariff documents for the 90 utilities in the sample to establish the actual electricity prices paid by commercial customers. The tariff documents encompassed a variety of pricing strategies, including time-of-use rates. Because we did not want to speculate whether TOU rates would exist in a partially or fully deregulated market, we kept TOU rates in the tariffbased analysis. As described below, based on the electricity prices described in the tariffs, marginal pricing is the basis for establishing electricity expenses in the LCC analysis. For most of the utilities in the sample, we collected tariff documents directly from their web sites. When web documents were not available, we contacted the utilities directly. The tariff documents reflect actual rates that customers pay for electricity.

Typically, a specific non-residential tariff is assigned to a particular customer based on that customer's annual peak demand. Following common utility practice, in the tariff analysis we combined commercial and industrial customers into one category. Our sampling strategy was to take the default tariff for each customer type, including TOU tariffs in the few cases where it was appropriate. We assigned every building in the 1033 simulation sample to one of the 17 subdivisions, and treated each building as a single customer. To increase the sample size and avoid bias in the electricity bill calculations, we assigned each customer to each utility in its subdivision. In other words, if we assign six utilities to a particular subdivision, we then assign the default tariff from each of the six utilities to each customer residing in that subdivision. Then we calculate an electric utility bill from each tariff assigned to the customer. Because we assigned, on average, almost six utilities to each of the 17 subdivisions, the above customer assignment method enabled us to effectively expand its building sample from 1033 to 6178 buildings. The particular tariff assigned to each customer was based on the annual peak demand for the base case EER level. We kept the customer on the same tariff for all standard levels.

For each of the 1033 buildings simulated, we processed the hourly simulation data for each standard level to compute the peak demand and total energy consumption for the 12 calendar months. For buildings assigned to TOU tariffs, we re-processed the hourly data to compute the peak demand and total energy consumption for the 12 calendar months during the peak, off-peak, and shoulder hours as defined by the utility. These data were entered into a billcalculating spreadsheet tool that estimated the total customer bill in each month. We repeated the calculation for each standard level and then totaled the monthly bills to arrive at an annual electricity bill. The difference between the annual bills for each standard level gave the associated operating cost savings. To compute the base case air conditioning expense, we took the annual bill and multiplied it by the ratio of the total air conditioning energy use to the total 
building electricity use. We calculated customer marginal prices as the net change in the total bill divided by the net change in energy consumption between two standard levels.

\section{(b) Hourly-Based Approach}

The goal of the hourly-based electricity price analysis was to estimate the real cost of meeting air conditioning loads for each building in each subdivision, and to translate these to cost savings that result from a given standard level. In this analysis, we treated each subdivision as if it were a single electricity system or control area, with a single hourly-varying marginal generation price. The dependence of system load on weather, and system price on load, creates a correlation between the weather-sensitive air conditioning load in each building and the time-varying generation marginal price. This substantially increases the cost of meeting air conditioning loads relative to base loads. Because we carried out the building simulations using Typical Meteorological Year (TMY) weather data to represent the correlations correctly, we had to produce a set of corresponding TMY system loads and prices for each subdivision. This was done by constructing a model for the load/temperature relationship, and a model for the price/load relationship, from historical data.

The analysis required hourly data for customer loads, local temperatures, system loads, and system prices. We took customer loads from the building simulations described above. Historical data on hourly loads are available from the Federal Energy Regulatory Commission (FERC) website through Form 714 filings. Historical data on hourly prices come from two sources: annual data submitted to FERC from regulated utilities and data developed from independent system operator websites. The FERC requires that each year a regulated utility submit FERC Form 714, which includes the "control area hourly system lambda" for each hour of the year in dollars per megawatt. A system lambda is the price of generating one additional unit of electricity. In the FERC Form 714, the system lambda represents the cost to meet the next kilowatt of load, as computed for the local control area of a particular utility using FERC's automatic dispatch methodology. For areas with deregulated wholesale electricity markets, i.e., New England, New York, California, and Pennsylvania-New Jersey-Maryland (PJM), we collected load data and day-ahead market clearing prices directly from the independent system operator (ISO) websites. The analysis required two types of weather data: historical and yeartypical data. We purchased historical data used to construct the models for the years 1999 and 2000 from the National Climatic Data Center. Typical Meteorological Year weather data is available from the National Renewable Energy Laboratory.

We computed the energy-cost savings due to a given standard level, assuming that the electricity provider passed all savings on to the customer. The savings have two components: avoided generation costs and avoided capacity costs. We computed avoided generation costs as the sum over each hour of the customer's marginal energy savings times the hourly marginal price, multiplied by factors accounting for additional costs that scale with generation (such as ancillary services) and energy losses. We computed the total avoided capacity costs as a total cost per kilowatt of capacity times the customer's load reduction during the hour of the system peak. The total cost per kilowatt for capacity included generation, transmission, and distribution 
capacity, and factors that account for losses and reserve margins. We converted the electricity provider's avoided capacity costs to annual customer savings by applying a fixed charge rate (FCR). The FCR is a factor that converts a given capacity investment to the annual revenue requirement needed to cover all costs associated with the investment. In deregulated wholesale markets, hourly prices are assumed to include a margin to cover generation capacity investments, so we did not include these costs in the model. Instead, we computed reductions to the electricity provider's annual installed capacity payments that result from the standard.

\section{(c) Comparison of Tariff-Based and Hourly Based Prices}

Table 10 summarizes the results for both the tariff-based and hourly-based methodologies. We computed the marginal price associated with air conditioning loads in each subdivision by taking the ratio for each building of the total cost savings to the total energy-savings between standard levels 9.5 EER and 11.0 EER. We then computed the weighted-average value for each subdivision. The table also includes the percentage of the marginal price attributable to demand charges for the tariff-based analysis and to capacity charges for the hourly-based analysis.

As Table 10 shows, the average effective marginal prices computed from the two approaches vary considerably in most regions, but the national averages are very close. Thus, on a national basis, the estimated marginal electricity price a provider would charge customers to supply electricity for an air conditioning end use is not substantially different than the price a customer currently pays under today's tariffs. Therefore, the national LCC results from the two different approaches are not significantly different. 
Table 10 Marginal Prices Computed from Air Conditioning Load Reductions Using the Tariff-based and Hourly-based Electricity Price Models

\begin{tabular}{|c|c|c|c|c|c|c|c|}
\hline \multirow[b]{2}{*}{ Subdivision } & \multirow[b]{2}{*}{ Weight* } & \multirow[b]{2}{*}{ Census Division } & \multirow[b]{2}{*}{ Region } & \multicolumn{2}{|c|}{ Tariff-based } & \multicolumn{2}{|c|}{ Hourly based } \\
\hline & & & & $\begin{array}{c}\text { Marginal } \\
\mathbf{c} / \mathbf{k W h}\end{array}$ & $\begin{array}{c}\% \\
\text { Demand }\end{array}$ & $\begin{array}{c}\text { Marginal } \\
\mathbf{c} / \mathbf{k W h}\end{array}$ & $\begin{array}{c}\% \\
\text { Capacity }\end{array}$ \\
\hline 1 & 4.7 & New England & New England & 9.5 & $53 \%$ & 10.7 & $43 \%$ \\
\hline 2.1 & 7.4 & Middle Atlantic & New York & 14.6 & $53 \%$ & 10.5 & $35 \%$ \\
\hline 2.2 & 5.6 & Middle Atlantic & $\mathrm{PA}, \mathrm{NJ}$ & 10.5 & $27 \%$ & 8.7 & $48 \%$ \\
\hline 3 & 13.7 & East North Central & WI,IL,IN,OH,MI & 10.8 & $46 \%$ & 11.0 & $65 \%$ \\
\hline 4.1 & 0.8 & West North Central & $\mathrm{MN}, \mathrm{IA}, \mathrm{MO}$ & 6.2 & $44 \%$ & 8.4 & $60 \%$ \\
\hline 4.2 & 4.7 & West North Central & $\mathrm{ND}, \mathrm{SD}, \mathrm{NE}, \mathrm{KS}$ & 7.1 & $30 \%$ & 9.8 & $60 \%$ \\
\hline 5.1 & 5.6 & South Atlantic & DE,MD,VA,WV & 7.9 & $41 \%$ & 9.9 & $63 \%$ \\
\hline 5.2 & 7.9 & South Atlantic & $\mathrm{NC}, \mathrm{SC}, \mathrm{GA}$ & 7.3 & $22 \%$ & 7.4 & $68 \%$ \\
\hline 5.3 & 6.6 & South Atlantic & Florida & 8.0 & $36 \%$ & 11.0 & $66 \%$ \\
\hline 6.1 & 5.1 & East South Central & KY,TN & 6.5 & $38 \%$ & 8.0 & $68 \%$ \\
\hline 6.2 & 5.4 & East South Central & MS,AL & 6.1 & $39 \%$ & 12.8 & $70 \%$ \\
\hline 7.1 & 5.3 & West South Central & OK,AR,LA & 5.8 & $26 \%$ & 11.6 & $76 \%$ \\
\hline 7.2 & 9.5 & West South Central & Texas & 10.0 & $23 \%$ & 10.8 & $75 \%$ \\
\hline 8.1 & 0.6 & Mountain & MT,ID,WY & 6.1 & $20 \%$ & 4.5 & $43 \%$ \\
\hline 8.2 & 4.2 & Mountain & $\mathrm{NV}, \mathrm{UT}, \mathrm{CO}, \mathrm{AZ}, \mathrm{NM}$ & 8.8 & $35 \%$ & 9.5 & $69 \%$ \\
\hline 9.1 & 1.7 & Pacific & WA,OR & 4.5 & $33 \%$ & 5.4 & $24 \%$ \\
\hline 9.2 & 11.2 & Pacific & California & 18.5 & $21 \%$ & 8.5 & $46 \%$ \\
\hline USA & 100.0 & & USA & 10.0 & $35 \%$ & 9.9 & $60 \%$ \\
\hline
\end{tabular}

* weight in the national average

In a previous rulemaking, ${ }^{\text {a }}$ DOE calculated marginal prices for commercial buildings that used residential-size $(<65,000 \mathrm{Btu} / \mathrm{h})$ central air conditioners and heat pumps. Also at that time, DOE collected tariffs in 1998 for thirty utilities. The mean of the distribution of the tariffs was $8.1 \phi / \mathrm{kWh}$, which is about $2 \phi / \mathrm{kWh}$ lower than the value computed for this analysis. Some of the reasons for the difference between that sample and the samples used for this analysis are:

- $\quad$ The earlier tariff sample was much smaller and included only a few publicly-owned

${ }^{\text {a }}$ DOE issued a Final Rule for the residential central air conditioner and heat pump rulemaking on May 23, 2002, 67 FR 36368. Details on the technical analysis conducted for the rulemaking can be found in the Technical Support Document.

$<$ http://www.eere.energy.gov/buildings/appliance_standards/residential/ac_central.html $>$ 
companies, and only one tariff per company.

- The earlier tariff sample did not include "time-of-use" or "block-by-demand" tariffs; excluding these tariffs tends to underestimate the effective marginal price.

- The earlier analysis did not use the level of regional dis-aggregation used in this analysis. This tends to average out the correlations between hot summer temperatures and the high prices, and contribute to higher effective marginal prices for air conditioning.

- $\quad$ The tariff sample collected in 1998 did not reflect the increase in electricity prices associated with deregulation, which occurred in 2000 to 2001 . We used EIA's Annual Energy Outlook forecast to project electricity prices out to the year of implementation of the standard, which removes this price increase by 2005. This is an important consideration when comparing the base year numbers for the two analyses.

- The residential central air conditioner analysis did not have an accurate method of calculating the relative proportion of peak demand reduction to energy savings, which is an important input to the effective marginal price calculation.

\subsubsection{Electricity Price Trend}

The electricity price trend provides the relative change in electricity prices for future years out to the year 2030. Estimating future electricity rates is very difficult, especially considering that there are efforts in many states throughout the country to restructure the electricity supply industry. In a regulated electricity market, each building is assigned to a particular utility company, and the rates offered by that utility can be obtained from surveys. With restructuring, customers in the future will be able to purchase electricity from a large set of suppliers.

We applied a projected trend in national average electricity prices to each customer's energy prices. In the LCC analysis, the following four scenarios can be analyzed:

- $\quad$ Constant energy prices at 2001 values

- $\quad$ AEO2003, High Economic Growth

- $\quad A E O 2003$, Reference Case

- $\quad A E O 2003$, Low Economic Growth

Figure 3 shows the trends for the three $A E O 2003$ price projections. We extrapolated the values in later years (i.e., after 2025) from their relative sources because $A E O 2003$ does not forecast beyond 2025. To arrive at values for these later years, we used the price trend from 2015 to 2025 of the forecast to establish prices in the years 2025 to 2035 . This method of extrapolation is in line with methods currently used by the EIA to forecast fuel prices for the Federal Energy Management Program (FEMP).

The default electricity price trend scenario used in the LCC analysis is the trend from the AEO2003 Reference Case. 


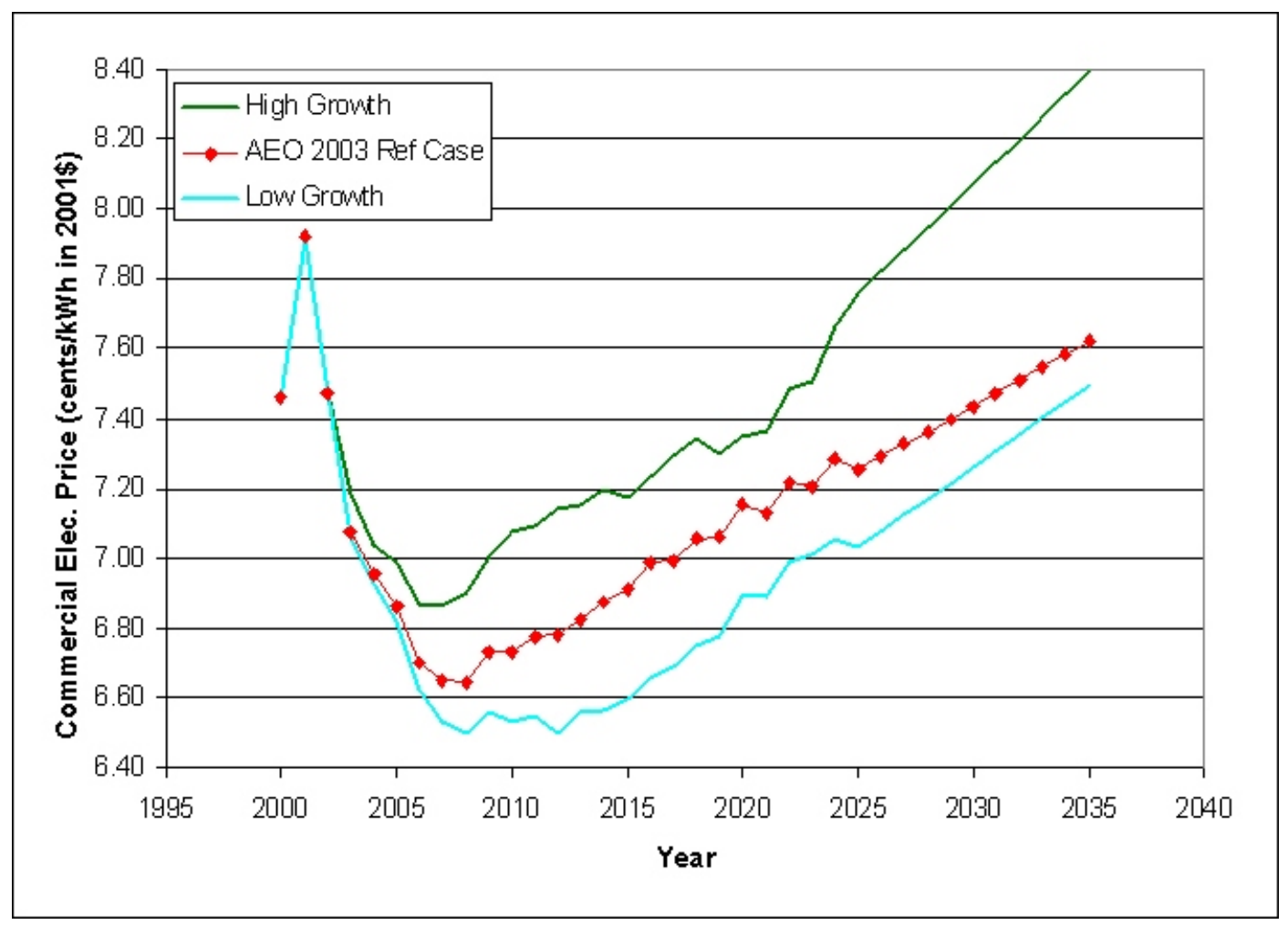

Figure 3 Electricity Price Trends for Commercial Rates 


\subsubsection{Repair Cost}

The repair cost is the cost to the consumer for replacing or repairing components in the air-conditioning equipment which have failed. We based the annualized repair cost for baseline efficiency air-conditioning equipment (i.e., the cost the customer pays annually for repairing the equipment) on the following expression:

$$
R C=\frac{0.5 \cdot E Q P}{L I F E}
$$

where $E Q P$ is the equipment price (customer price for the equipment only), and $L I F E$ is the average lifetime of the equipment (15.4 years).

Because data were not available to indicate how repair costs vary with equipment efficiency, we considered two scenarios: 1) repair costs which varied in direct proportion with the manufacturer price of the equipment, and 2) repair costs which were kept flat (i.e., did not increase with efficiency). We used repair costs which vary with manufacturer price as the default annualized repair cost scenario in the LCC and PBP analysis. Spreadsheets used in calculating the LCC and PBP are able to calculate LCC and PBP based on the constant repair cost scenario.

For the case where repair costs are a function of equipment price, Table 11 shows the weighted-average annualized repair costs for the baseline level and each standard level for the two classes of commercial air conditioners. Since equipment prices are a function of variables which are represented by distributions rather than single point-values (i.e., manufacturer price, markups, and sales tax), repair costs are actually represented by a distribution of values rather than just the weighted-average values shown in Table 11.

Table 11 Weighted-average Annualized Repair Costs

\begin{tabular}{c|c|c}
\hline EER & $\begin{array}{c}\geq \mathbf{6 5 , 0 0 0 ~ B ~ t u / h ~ t o < 1 3 5 , 0 0 0 ~ B t u / h} \\
\text { Unitary Air Conditioners }\end{array}$ & $\begin{array}{c}\geq \mathbf{1 3 5 , 0 0 0} \text { Btu/h to }<240,000 ~ B t u / h \\
\text { Unitary Air Conditioners }\end{array}$ \\
\hline $9.5^{*}$ & - & $\$ 279$ \\
10.0 & - & $\$ 284$ \\
$10.1^{\dagger}$ & $\$ 151$ & - \\
10.5 & $\$ 155$ & $\$ 291$ \\
11.0 & $\$ 162$ & $\$ 303$ \\
11.5 & $\$ 174$ & $\$ 323$ \\
12.0 & $\$ 194$ & $\$ 355$ \\
\hline
\end{tabular}


* 9.5 EER is baseline efficiency for the $\geq 135,000 \mathrm{Btu} / \mathrm{h}$ to $<240,000 \mathrm{Btu} / \mathrm{h}$ equipment class

$\dagger$ 10.1 EER is baseline efficiency for the $\geq 65,000 \mathrm{Btu} / \mathrm{h}$ to $<135,000 \mathrm{Btu} / \mathrm{h}$ equipment class

\subsubsection{Maintenance Cost}

The maintenance cost is the cost to the consumer of maintaining equipment operation. The maintenance cost is not the cost associated with the replacement or repair of components that have failed (this is covered by the repair cost discussed above). Rather, the maintenance cost is associated with general maintenance (e.g., checking and maintaining refrigerant charge levels and cleaning heat exchanger coils).

We took annualized maintenance costs for commercial air conditioners from data in $R S$ Means Facilities Maintenance \& Repair Cost Data, 1995. ${ }^{5}$ This source provides estimates on the person-hours, labor rates, and materials required to maintain commercial air-conditioning equipment. $R S$ Means specifies the following 11 actions that constitute required annual maintenance:

- $\quad$ Check with operating or area personnel for deficiencies

- $\quad$ Check tensions, condition, and alignment of belts; adjust as necessary

- $\quad$ Lubricate shaft and motor bearings

- $\quad$ Replace air filters

- Clean electrical wiring and connections; tighten loose connections

- Clean coils, evaporator drain pan, blowers, fan motors, and drain piping as required

- $\quad$ Perform operational check of unit; make adjustments on controls and other components as required

- During operation of unit, check refrigerant pressure; add refrigerant as necessary

- $\quad$ Check compressor oil level; add oil as required

- $\quad$ Clean area around unit

- $\quad$ Fill out maintenance checklist and report deficiencies

We calculated the annualized maintenance cost by multiplying the number of personhours by the corresponding labor rate and adding to it the associated materials costs. RS Means provides specific cost data for the maintenance of roof top air conditioners ranging in cooling capacity from 3 through 24 tons. Since the maintenance cost data in RS Means provides no distinction based on cooling capacity (at least between 3 and 24 tons), we took the roof top air conditioner data to be representative of maintenance costs for both the $\geq 65,000 \mathrm{Btu} / \mathrm{h}$ to $<$ $135,000 \mathrm{Btu} / \mathrm{h}$ equipment class and the $\geq 135,000 \mathrm{Btu} / \mathrm{h}$ to $<240,000 \mathrm{Btu} / \mathrm{h}$ equipment class.

Because data were not available to indicate how maintenance costs vary with equipment efficiency, we decided to use costs that stay constant as equipment efficiency increased.

Table 12 summarizes the nationally representative annualized maintenance costs for 3-ton through 24-ton roof top air conditioners as presented in RS Means. Both bare maintenance costs 
(i.e., costs before O\&P) and maintenance costs including O\&P are provided. The maintenance costs that include O\&P were chosen to represent the maintenance costs for baseline efficient systems.

Table 12 Annualized Maintenance Costs for Baseline Air Conditioners

\begin{tabular}{|c|c|c|c|c|c|c|c|c|c|}
\hline \multirow[b]{2}{*}{ System Type } & \multirow[b]{2}{*}{$\begin{array}{c}\text { Annual } \\
\text { Person- } \\
\text { hours }\end{array}$} & \multicolumn{4}{|c|}{ Bare Costs (2001\$) } & \multicolumn{4}{|c|}{ Labor and Materials w/ O\&P (2001\$) } \\
\hline & & Mat'l & $\begin{array}{l}\text { Cost } \\
\text { per } \\
\text { Person- } \\
\text { hour }\end{array}$ & $\begin{array}{c}\text { Annual } \\
\text { Labor } \\
\text { Cost }\end{array}$ & $\begin{array}{c}\text { Annual } \\
\text { Total } \\
\text { Cost }\end{array}$ & Mat'l & $\begin{array}{c}\text { Cost } \\
\text { per } \\
\text { Person- } \\
\text { hour }\end{array}$ & $\begin{array}{c}\text { Annual } \\
\text { Labor } \\
\text { Cost }\end{array}$ & $\begin{array}{c}\text { Annual } \\
\text { Total } \\
\text { Cost }\end{array}$ \\
\hline $\begin{array}{l}\text { Package unit, air-cooled, } \\
3 \text {-tons through } 24 \text {-tons }\end{array}$ & 2.402 & $\$ 51.71 *$ & $\$ 36.20^{\dagger}$ & $\$ 86.95$ & $\$ 139$ & $\$ 64.64 *$ & $\$ 54.60^{\dagger}$ & $\$ 135.33$ & $\$ 200$ \\
\hline
\end{tabular}

* 2001 material costs were derived by multiplying the 1996 material costs provided in the RS Means Facilities Maintenance \& Repair Cost Data, 1995 by the ratio of the producer price index values for unitary air conditioners for the years 2001 and 1996 (123.7 and 119.6, respectively) from the U.S. Department of Labor, Bureau of Labor Statistics. ${ }^{6}$

${ }^{\dagger}$ Labor rates from RS Means Mechanical Cost Data, 2002 for steamfitter or pipefitter.

\subsubsection{Lifetime}

We define lifetime as the age at which an air conditioner is retired from service. We based the median lifetime of commercial air conditioners on data from the 1999 ASHRAE HVAC Applications Handbook, ${ }^{7}$ which gives a median lifetime of 15 years for roof top air conditioners. We found no other data to indicate a different median or mean lifetime for commercial airconditioning equipment.

Because equipment lifetime is more accurately represented with a survival function rather than a single-point value, a survival function was created for commercial air conditioners based on data for residential heat pump systems. We based our estimate of the shape of the survival function for commercial air conditioners on a survey performed for the Electric Power Research Institute of 2,184 heat pump installations in a seven-state region of the United States. ${ }^{8}$ The first step in creating the survival function for commercial air conditioners was to approximate the shape of the actual survival function for residential heat pumps. To do this, we used a Weibull distribution. The equation representing the Weibull cumulative distribution function is:

$$
F(\operatorname{ag} e, \alpha, \beta)=1-e^{(\operatorname{age} / \beta)^{\alpha}}
$$

where age is the age of the air conditioner, and $\alpha$ and $\beta$ equal alpha and beta, two parameters of the Weibull distribution.

We varied both alpha and beta until the Weibull cumulative distribution was roughly equal to the actual survival function for residential heat pumps. Through a trial and error process, values of 4.00 and 19.76 were chosen for alpha and beta, respectively. In order to create a survival function for commercial air conditioners, the value for alpha (4.00) was held constant and beta was varied until the Weibull cumulative distribution yielded a median value of 15 . The 
resulting value for beta was 16.44. Alpha was held constant because it defines the shape of the function.

Figure 4 shows the actual survival function for residential heat pumps, the Weibull-based survival function for residential heat pumps, and the Weibull-based survival function created for commercial air conditioners used in the LCC analysis. (Note that the survey we used to establish the actual survival function for residential heat pumps covered only the first 19 years of the equipment's life. In order to complete the entire survival function, we used an extrapolation based on estimates performed by others. ${ }^{9}$ ) The Weibull-based survival function for residential heat pumps closely approximates the actual survival function until the $23^{\text {rd }}$ year. Because the actual survival function ends abruptly in the $24^{\text {th }}$ year, the Weibull-based function no longer approximates the actual function after the $23^{\text {rd }}$ year. The mean lifetime from the derived Weibullbased commercial air conditioner survival function is 15.4 years.

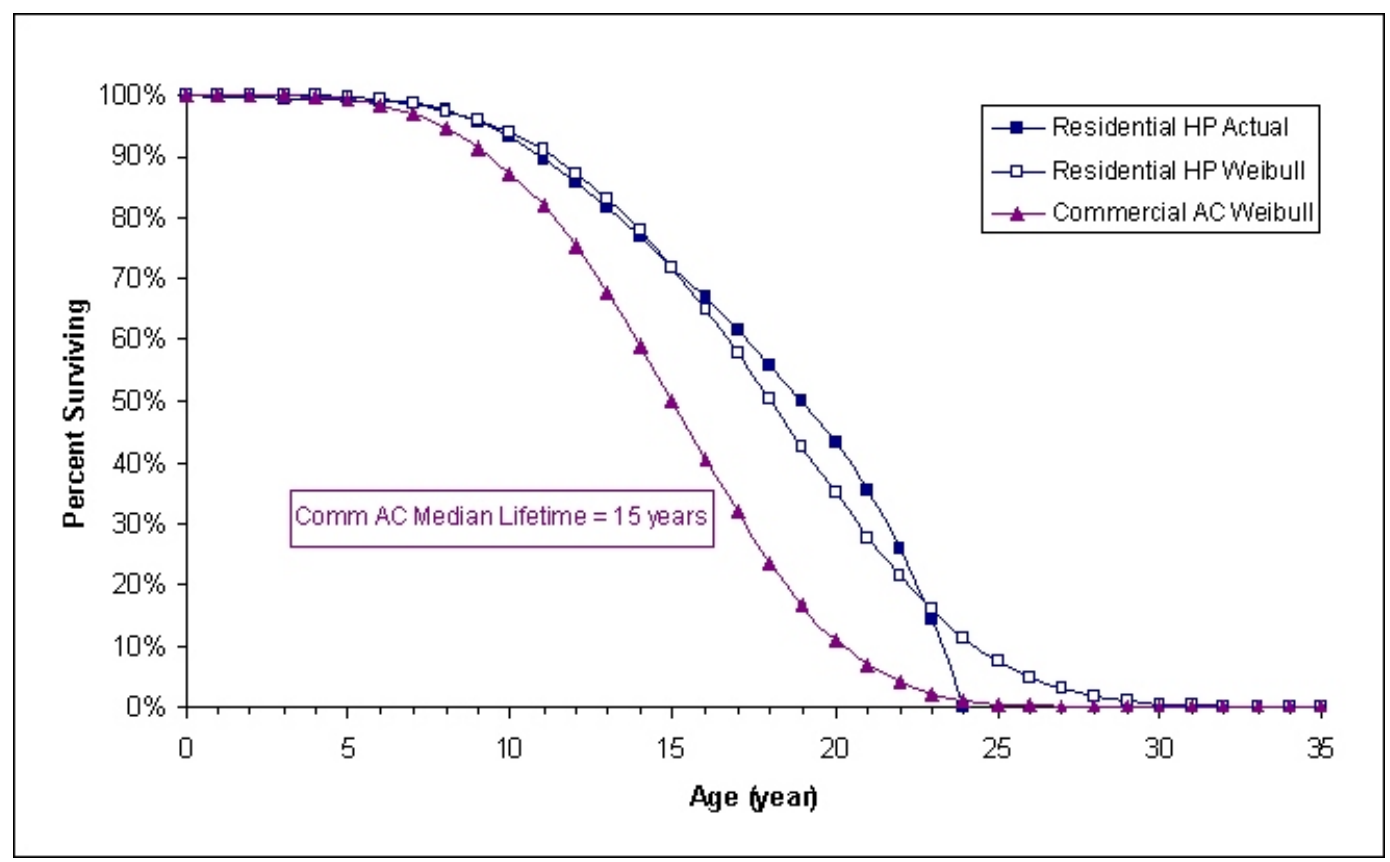

\section{Figure 4 Survival Functions for Commercial Air Conditioners and Residential Heat Pumps}

\subsubsection{Discount Rate}

The discount rate is the rate at which future expenditures are discounted to establish their present value. We derived the discount rates for the commercial air conditioner analysis by estimating the cost of capital of companies that purchase commercial air-conditioning equipment. The cost of capital is commonly used to estimate the present value of cash flows to be derived from a typical company project or investment. ${ }^{10}$ Most companies use both debt and equity 
capital to fund investments, so their cost of capital is the weighted average of the cost to the firm of equity and debt financing.

We estimated the cost of equity financing by using the capital asset pricing model (CAPM). The CAPM, among the most widely used models to estimate the cost of equity financing, assumes that the cost of equity is proportionate to the amount of systematic risk associated with a firm. The cost of equity financing tends to be high when a firm faces a large degree of systematic risk, and it tends to be low when the firm faces a small degree of systematic risk.

We determined the cost of equity financing by the risk coefficient of a firm (beta), the expected return on "risk free" assets $\left(R_{f}\right)$, and the additional return expected on assets facing average market risk, also known as the equity risk premium or ERP. The risk coefficient or "beta" indicates the degree of risk associated with a given firm relative to the level of risk (or price variability) in the overall stock market. Betas usually vary between 0.5 and 2.0. A firm with a beta of 0.5 faces half the risk of other stocks in the market; a firm with a beta of 2.0 faces twice the overall stock market risk.

The following equation gives the cost of equity financing for a particular company:

$$
k_{e}=R_{f}+(\beta \cdot E R P)
$$

where:

$k_{e}=$ the cost of equity for a company,

$R_{f}=$ the expected return of the risk free asset,

$\beta=$ the beta of the company stock, and

$E R P=$ the expected equity risk premium.

We defined the risk free rate as the yield (December 2001) on long-term government bonds. ${ }^{11}$ We used a 5.5 percent estimate for the ERP based on data from the Damodaran Online site. $^{12}$

The cost of debt financing is the yield or interest rate paid on money borrowed by a company (for example, by selling bonds). As defined here, the cost of debt includes compensation for default risk (the risk that a firm will go bankrupt) and excludes deductions for taxes. We estimated the cost of debt for companies by adding a risk adjustment factor to the current yield on long term corporate bonds (the risk free rate). We based the adjustment factor on indicators of company risk, such as credit rating or variability of stock returns.

The weighted average cost of capital (WACC) of a company is the weighted average cost of debt and equity financing:

$$
k=k_{e} \cdot w_{e}+k_{d} \cdot w_{d}
$$


where:

$k=\quad$ the (nominal) cost of capital,

$k_{e}=$ the expected rate of return on equity,

$k_{d}=$ the expected rate of return on debt,

$w_{e}=$ the proportion of equity financing in total annual financing, and

$w_{d}=$ the proportion of debt financing in total annual financing.

The cost of capital is a nominal rate, because it includes anticipated future inflation in the expected returns from stocks and bonds. The real discount rate or WACC deducts expected inflation $(r)$ from the nominal rate. We calculated expected inflation ( 2.3 percent) from the average of the last five quarters' change in gross domestic product (GDP) prices. $^{13}$

To estimate the WACC of commercial air conditioner purchasers, we used a sample of companies drawn from a database of 7,319 U.S. companies given on the Damodaran Online site. This database includes most of the publicly-traded companies in the U.S.

We divided the companies into the nine categories shown in Table 13 according to their type of activity. We sought financial information for only 10 percent of the industrial and office/service sector firms in the full sample to keep the database manageable. We chose the 10 percent sub-sample by listing the companies alphabetically and drawing every tenth firm on the list. In cases where one or more of the variables needed to estimate the discount rate was missing or could not be obtained, we discarded the firm from the analysis. Overall, we discarded about 80 percent of the firms in the full database for this reason. Table 13 describes the economic sectors represented in each of the categories as well as the number of companies used for determining discount rates. Ultimately, we used a sample of 973 companies to represent commercial air conditioner purchasers.

Table 13 Description of Companies Included in Discount Rate Sample

\begin{tabular}{|c|c|c|c|c|}
\hline Category & Economic Sectors & SIC Codes & $\begin{array}{c}\text { Full US } \\
\text { Firm } \\
\text { Sample (1) } \\
\end{array}$ & $\begin{array}{c}\text { Discount } \\
\text { Rate Sub- } \\
\text { Sample } \\
\end{array}$ \\
\hline Retail stores & Retail & $53,54,56$ & 280 & 218 \\
\hline Property owners and managers & $\begin{array}{l}\text { Holding companies, real estate } \\
\text { companies }\end{array}$ & 6720 & 152 & 11 \\
\hline Medical services & $\begin{array}{l}\text { Hospitals and medical service } \\
\text { companies }\end{array}$ & 8000 & 207 & 115 \\
\hline Industrial companies & $\begin{array}{l}\text { Mining, manufacturing, transportation, } \\
\text { communications }\end{array}$ & $1000-4000$ & 3913 & 253 \\
\hline Lodging & Hotels & 7000 & 84 & 51 \\
\hline Food service companies & Restaurants, grocery stores & 5400,5812 & 121 & 88 \\
\hline Office/Service sector & Banks, financial services, offices & $5910-9913$ & 2391 & 128 \\
\hline Public not for profit & Public services, religious & N.A. & 41 & 41 \\
\hline Public for profit & Educational services, entertainment & 7950,8299 & 130 & 68 \\
\hline
\end{tabular}

Source: Lawrence Berkeley National Laboratory (LBNL) calculations applied to firms sampled from the Damodaran Online data site 
For each firm in the sample, we derived the cost of debt, percent debt financing, and systematic firm risk from information provided at the Damodaran Online site, Bloomberg Professional, ${ }^{14}$ and FERC Form 1 filings (for public utilities). ${ }^{15}$ We estimated the cost of debt financing from the long-term government bond rate ( 5.5 percent) and the standard deviation of the stock price. For the public not-for-profit subsector, we based the cost of capital on average interest rates for Treasury, state, and municipal bonds. Table 14 shows average values for the cost of debt, percent debt financing, and systematic firm risk for the sample companies.

\begin{tabular}{lcl} 
Table 14 & Average Values for Variables Used to Estimate Company Discount Rates \\
\hline Variable & Average Value & \multicolumn{1}{c}{ Source } \\
\hline Risk free asset return $\left(R_{f}\right)$ & $5.5 \%$ & Bloomberg Financial. December 2001 \\
Equity risk premium $(E R P)$ & $5.5 \%$ & Stern Business School, Damodaran Online \\
Expected inflation $(r)$ & $2.3 \%$ & Bureau of Economic Analysis \\
Cost of debt (after tax $)\left(k_{d}\right)$ & $5.9 \%$ & Stern Business School, Damodaran Online \\
Percent debt financing $\left(w_{d}\right)$ & $44 \%$ & Stern Business School, Damodaran Online \\
Systematic firm risk $(\beta)$ & 0.93 & Stern Business School, Damodaran Online \\
\hline
\end{tabular}

The WACC varies among the categories. To estimate the shares of major categories in total commercial sector purchases of commercial air conditioners, we used the share of each category in total commercial building square footage with package air-conditioning, as given by EIA's 1999 CBECS. ${ }^{16}$ Table 15 gives the results.

Table 15 Estimated Shares of Commercial Air Conditioner Purchases by Category

\begin{tabular}{lc}
\hline Category & Percent* \\
\hline Retail stores & $16.5 \%$ \\
Property owners and managers & $21.2 \%$ \\
Medical services & $6.7 \%$ \\
Industrial firms & $4.9 \%$ \\
Lodging & $4.0 \%$ \\
Food service companies & $5.3 \%$ \\
Office/Service sector & $19.4 \%$ \\
Public not for profit & $11.0 \%$ \\
Public for profit & $11.0 \%$ \\
\hline
\end{tabular}

Source: 1999 CBECS 


\footnotetext{
* The share of total square footage occupied by property owners is actually $42 \%$. However, in some of these buildings the tenants purchase commercial air conditioners. We assumed that this is the case for half of the square footage occupied by property owners. DOE allocated this quantity among the other categories in proportion to their shares of total square footage.
}

Table 16 shows the estimates of the real discount rate by category. The average discount rate, weighted by the category shares of total air conditioner purchases, is 6.1 percent.

Table 16 Real Discount Rates by Category

\begin{tabular}{|c|c|c|c|c|c|}
\hline Category & SIC Code & $\begin{array}{c}\text { Category } \\
\text { Share of } \\
\text { Purchases }\end{array}$ & $\begin{array}{c}\text { Mean Real } \\
\text { Discount Rate } \\
\text { (WACC) }\end{array}$ & $\begin{array}{l}\text { Standard } \\
\text { Deviation }\end{array}$ & $\begin{array}{c}\text { Number of } \\
\text { Observations }\end{array}$ \\
\hline Retail stores & $53,54,56$ & $16.5 \%$ & $7.1 \%$ & $2.1 \%$ & 218 \\
\hline Property owners and managers & 6720 & $21.2 \%$ & $5.2 \%$ & $0.7 \%$ & 11 \\
\hline Medical services & 8000 & $6.7 \%$ & $7.0 \%$ & $1.7 \%$ & 115 \\
\hline Industrial companies & $1000-4000$ & $4.9 \%$ & $6.9 \%$ & $3.2 \%$ & 253 \\
\hline Hotels & 7000 & $4.0 \%$ & $5.6 \%$ & $1.5 \%$ & 51 \\
\hline Food service companies & 5400,5812 & $5.3 \%$ & $6.1 \%$ & $1.4 \%$ & 88 \\
\hline Office/Service sector & $5910-9913$ & $19.4 \%$ & $6.9 \%$ & $2.1 \%$ & 128 \\
\hline Public not for profit & N.A. & $11.0 \%$ & $3.0 \%$ & $0.7 \%$ & 41 \\
\hline Public for profit & 7950,8299 & $11.0 \%$ & $7.3 \%$ & $1.8 \%$ & 68 \\
\hline Weighted Average & & N.A. & $6.1 \%$ & $1.6 \%$ & N.A. \\
\hline
\end{tabular}

Source: CBECS, Damodaron Online and LBNL calculations

Retail firms, property owners and medical service companies purchase the bulk of commercial air conditioners, so the discount rates calculated for those sectors are particularly important. Retail and property owner discount rates were estimated to average 7.1 percent and 5.2 percent, respectively. Medical service discount rates were estimated to average 7.0 percent. These figures are after-tax discount rates, representing the return required by such firms to attract financing. They fall between discount rate estimates available from Ibbotson Associates ${ }^{17}$ and Bloomberg Professional, ${ }^{18}$ two influential financial data companies. The Bloomberg Professional online service estimates tend to be slightly lower (e.g., retail cost of capital equal to 5.2 percent after deducting 2.3 percent for inflation) and Ibbotson Associates estimates tend to be somewhat higher (e.g., retail cost of capital equal to 9.2 percent). The different estimates available from Bloomberg and Ibbotson result from different assumptions about expected bond rates, risk premium and other variables.

Our approach for estimating the cost of capital provides a measure of the discount rate 
spread as well as the average discount rate. The discount rate spread by ownership category is inferred from the standard deviation, which ranges between 0.7 percent and 3.2 percent. The distribution of the weighted average discount rate reflects the discount rate distributions of all nine ownership categories (Figure 5).

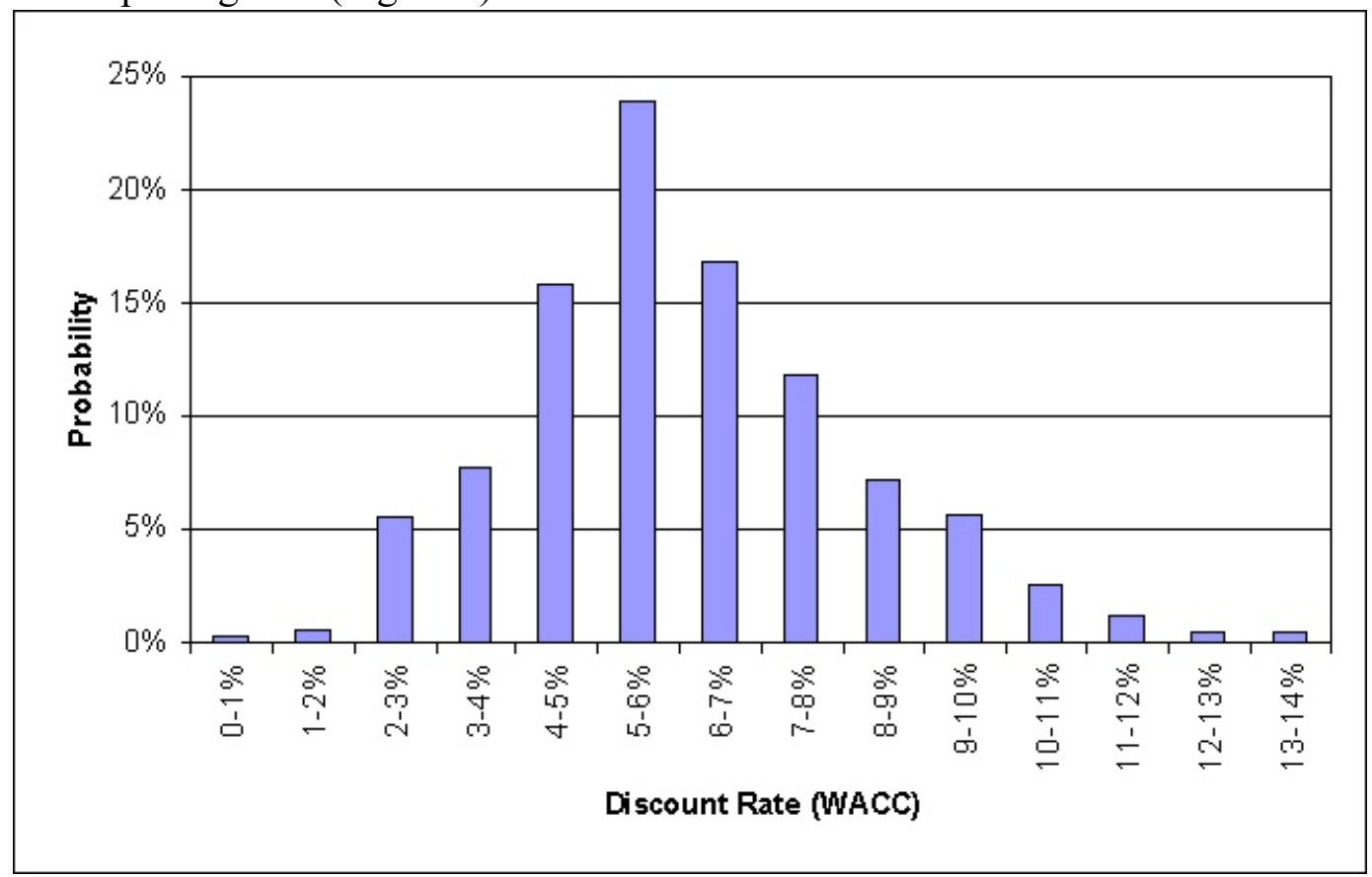

Figure 5 Distribution of Discount Rates for All Ownership Categories

Discount rates are particularly sensitive to the size of the equity risk premium (ERP) and the risk free rate. Thus, a sensitivity analysis was conducted to evaluate the effects of changes in these variables. The ERP is based on expectations about future stock market growth and it is not surprising that estimates of the $E R P$ in the finance literature differ widely. The Bloomberg Professional financial service sets upper and lower bounds on the ERP at 1 percent and 10 percent, respectively. ${ }^{19}$

There is also variability in the expected risk free rate, which is based on the return to long term government bonds. For example, the return on long term government bonds averaged just under 5.5 percent between 1926-2000. ${ }^{20,21}$ However, average bond returns ranged between 4.0 percent in the first half and 7.0 percent in the second half of that period, holding expected inflation constant. ${ }^{22,23}$

In the sensitivity analysis, a lower bound estimate of company real discount rates was obtained by calculating the cost of capital of the companies in our sample assuming a 1 percent $E R P$ and a 4.0 percent risk free rate. An upper bound estimate of company real discount rates was obtained by estimating the cost of capital of companies assuming a 10 percent $E R P$ and a 7 percent risk free rate. 
Following these assumptions, the lower bound estimate of the discount rate was 2.5 percent (with ownership category rates ranging from 2.2 percent for property owners to 3.0 percent for public for profit). The upper bound estimate of the discount rate was 9.6 percent (with ownership category rates ranging from 3.0 percent for public for profit to 11.5 percent for retail stores (Table 17). The mid-range discount rate was 6.1 percent.

Table 17 Sensitivity of Real Discount Rates to Equity Risk Premium and Risk Free Rate

\begin{tabular}{|c|c|c|c|}
\hline & $\begin{array}{l}\text { Lower Bound Average } \\
\text { Real Discount Rate* }\end{array}$ & $\begin{array}{l}\text { Mid-Range Average } \\
\text { Real Discount Rate }\end{array}$ & $\begin{array}{c}\text { Upper Bound Average } \\
\text { Real Discount Rate }\end{array}$ \\
\hline Retail stores & $2.6 \%$ & $7.1 \%$ & $11.5 \%$ \\
\hline Property owners and managers & $2.2 \%$ & $5.2 \%$ & $8.2 \%$ \\
\hline Medical services & $2.7 \%$ & $7.0 \%$ & $11.4 \%$ \\
\hline Industrial companies & $2.5 \%$ & $6.9 \%$ & $11.2 \%$ \\
\hline Hotels & $2.3 \%$ & $5.6 \%$ & $9.0 \%$ \\
\hline Food service companies & $2.6 \%$ & $6.1 \%$ & $9.7 \%$ \\
\hline Office/Service sector & $2.5 \%$ & $6.9 \%$ & $11.3 \%$ \\
\hline Public not-for-profit ${ }^{\S}$ & $3.0 \%$ & $3.0 \%$ & $3.0 \%$ \\
\hline Public for profit & $2.8 \%$ & $7.3 \%$ & $11.8 \%$ \\
\hline Weighted-Average & $2.5 \%$ & $6.1 \%$ & $9.6 \%$ \\
\hline \multicolumn{4}{|c|}{ * Lower bound: $E R P$ set equal to $1 \%$ and risk free rate set to $4.0 \%$} \\
\hline \multicolumn{4}{|c|}{${ }^{\dagger}$ Mid-Range: $E R P$ set equal to $5.5 \%$ and risk free rate set to $5.5 \%$} \\
\hline \multicolumn{4}{|c|}{${ }^{\ddagger}$ Upper bound: $E R P$ set equal to $10 \%$ and risk free rate set to $7.0 \%$} \\
\hline
\end{tabular}

\subsubsection{Effective Date of Standard}

The effective date is the future date when a standard is to be implemented. In the case of commercial air conditioners, we expect air conditioner manufacturers to implement any new standard beginning in 2008. We calculated the LCC for all customers as if they each purchase a new commercial air conditioner in 2008 . We based the cost of the equipment on this year; however, all dollar values are expressed in 2001 dollars.

\section{PAYBACK PERIOD INPUTS}

\subsection{Definition}

The payback period (PBP) is the amount of time it takes the consumer to recover the assumed higher purchase expense of more energy-efficient equipment as a result of lower operating costs. Numerically, the PBP is the ratio of the increase in purchase expense (i.e., from a less efficient design to a more efficient design) to the decrease in annual operating expenditures. This type of calculation is known as a "simple" payback period, because is does not take into account changes in operating expense over time or the time value of money; that is, the calculation is done at an effective discount rate of 0 percent. 
The equation for PBP is:

$$
P B P=\frac{\triangle I C}{\triangle O C}
$$

where $\triangle I C$ is the difference in the total installed cost between the more efficient standard level and the base case design, and $\triangle O C$ is the difference in annual operating expenses. PBPs are expressed in years. PBPs greater than the life of the product mean that the increased total installed cost is not recovered in reduced operating expenses.

\subsection{Inputs}

The data inputs to PBP are the total installed cost of the equipment to the customer for each efficiency level and the annual (first year) operating expenditures for each efficiency level. The inputs to the total installed cost are the equipment price and the installation cost. The inputs to the operating costs are the annual energy cost, the annual repair cost, and the annual maintenance cost. The PBP uses the same inputs as the LCC analysis except that electricity price trends and discount rates are not required. Since the PBP is a "simple" payback, the required electricity rate is only for the year in which a new standard is to take effect, in this case, the year 2008. The electricity rate used in the PBP calculation was the price projected for that year.

\section{RESULTS USING TARIFF-BASED ELECTRICITY PRICES}

\subsection{LCC Results}

This section presents LCC results for the considered efficiency levels that are based on annual operating costs calculated from tariff-based electricity prices.

Since the value of most inputs is uncertain, we represented them as a distribution of values rather than a single point-value. Thus, we also represent the LCC results as a distribution of values. Before proceeding with the presentation of the distributional LCC results, we present average values for total installed costs, annual operating costs, and LCC to show how they vary with efficiency for each of the two commercial air conditioner equipment classes.

\subsubsection{LCC Breakdown Based Upon Average Input Values}

For each equipment class, Figures 6 through 11 show how, on an average basis, the total installed costs, annual operating costs, and LCC vary with efficiency (all costs are in 2001\$). We segmented the figures for total installed cost into equipment price and installation cost. We segmented the figures for annual operating cost into annual electricity, repair, and maintenance costs. For LCC, the figures are segmented into total installed cost and lifetime operating cost. Although these figures are based on mean or average values rather than results from the Monte 
Carlo simulation analysis, they demonstrate how the various inputs impact LCC.

In reviewing the total installed cost results for both equipment classes, the largest contributor to increased total installed cost is the equipment price since the installation cost remains relatively constant across efficiencies.

With regard to annual operating cost, the largest contributor to the overall operating cost at any efficiency level is the annual electricity cost. As efficiency increases, the electricity cost decreases. Even at the maximum efficiency level (12 EER), the drop in the annual electricity cost more than offsets the relatively small increase in repair costs. Note that because the maintenance cost is assumed to remain constant across all efficiency levels, it does not contribute to the change in the overall annual operating cost as efficiency increases.

The LCC results reveal that as efficiency increases, the lifetime operating cost has more of an impact on the LCC than the total installed cost. In other words, the increase in total installed cost that occurs when equipment efficiency is increased is offset by the decrease in lifetime operating costs. As a result, the LCC at all efficiency levels is lower than that for the baseline level. For both equipment classes, the minimum LCC occurs at an efficiency of 11.5 EER. For efficiencies beyond 11.5 EER, the incremental decrease in lifetime operating costs is offset by the incremental increase in total installed costs.

It is worth reiterating that the results shown in Figures 6 through 11 are based upon average input values rather than input distributions. Thus, although one can observe how the various inputs impact LCC and, in turn, how the resulting LCC change with efficiency, one should only draw conclusions from the distribution of LCC results that are presented in below. 


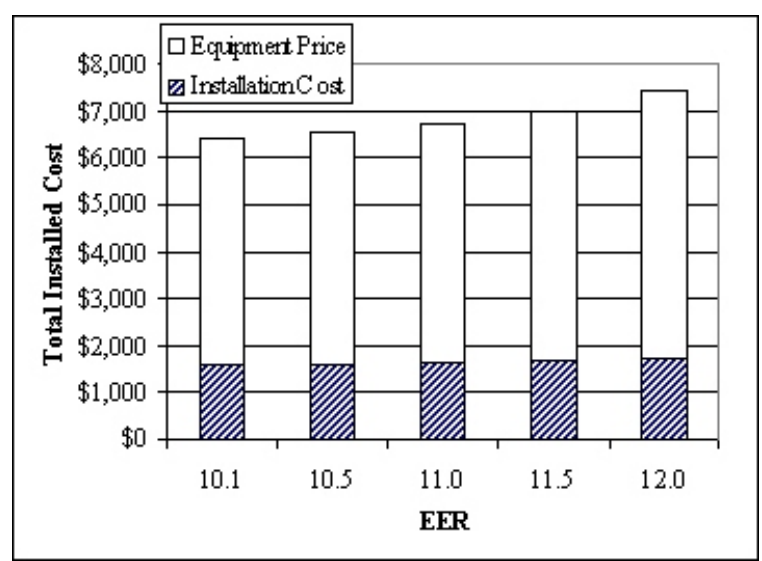

Figure $6 \geq 65,000 \mathrm{Btu} / \mathrm{h}$ to $<135,000 \mathrm{Btu} / \mathrm{h}$ : Mean Total Installed Costs

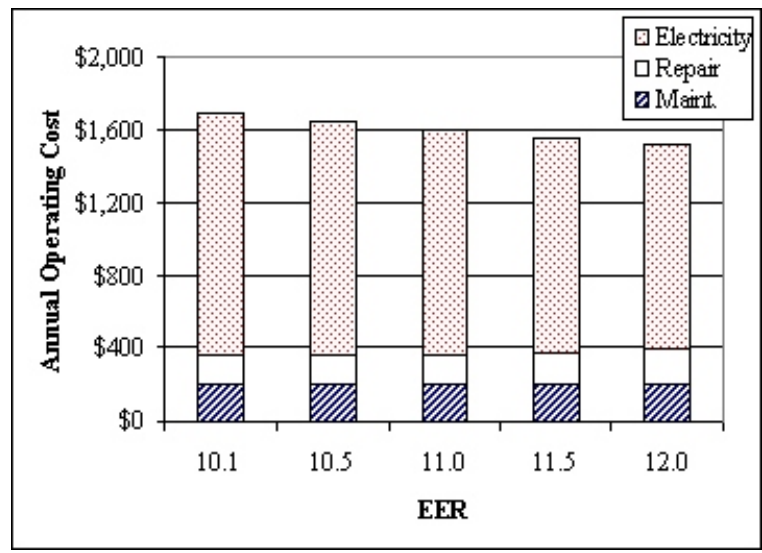

Figure $8 \geq 65,000 \mathrm{Btu} / \mathrm{h}$ to $<135,000 \mathrm{Btu} / \mathrm{h}$ :

Tariff-Based Mean Annual

Operating Costs

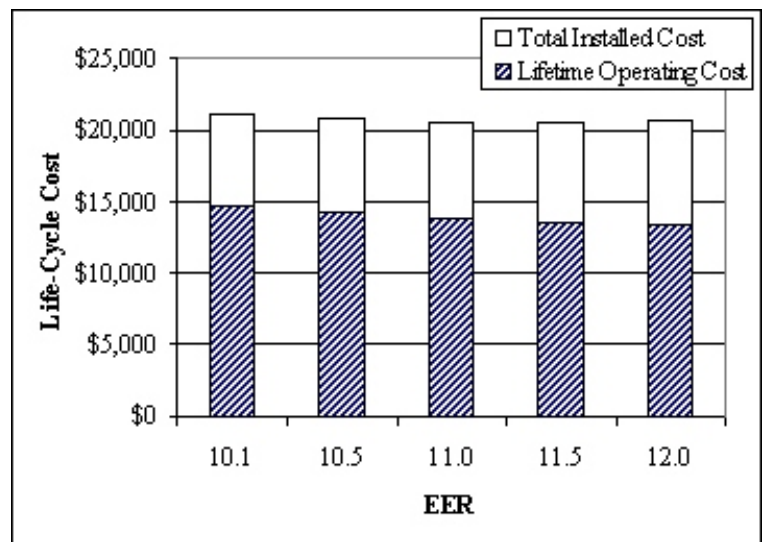

Figure $10 \geq 65,000 \mathrm{Btu} / \mathrm{h}$ to $<135,000 \mathrm{Btu} / \mathrm{h}$ :

Tariff-Based Mean Life-C ycle

Costs

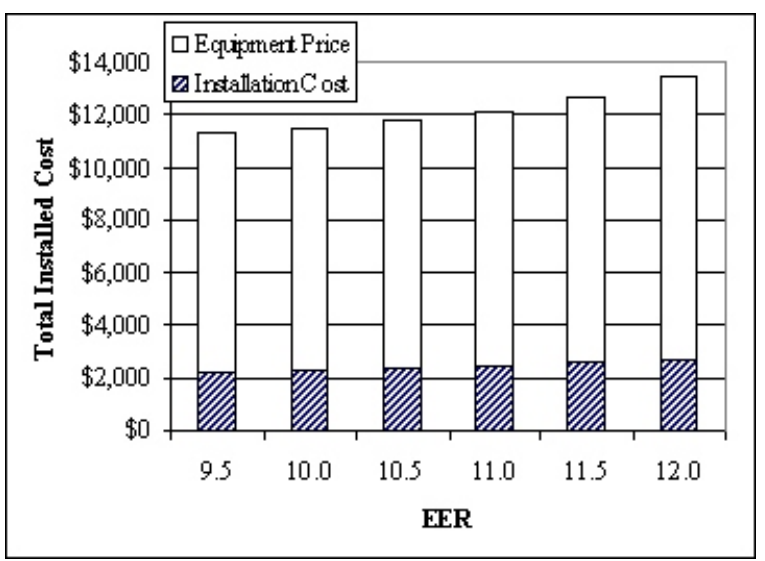

Figure 7

$\geq 135,000 \mathrm{Btu} / \mathrm{h}$ to $<240,000$

Btu/h: Mean Total Installed

Costs

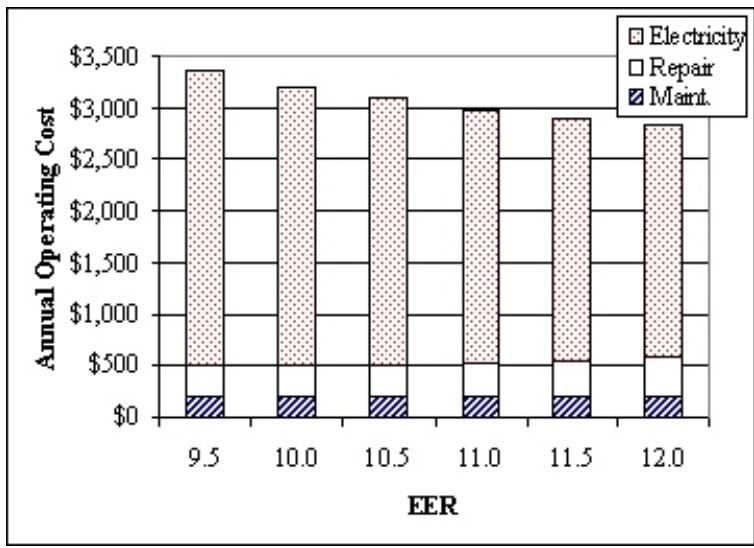

Figure 9

$\geq 135,000 \mathrm{Btu} / \mathrm{h}$ to $<240,000$

Btu/h: Tariff-Based Mean

Annual Operating Costs

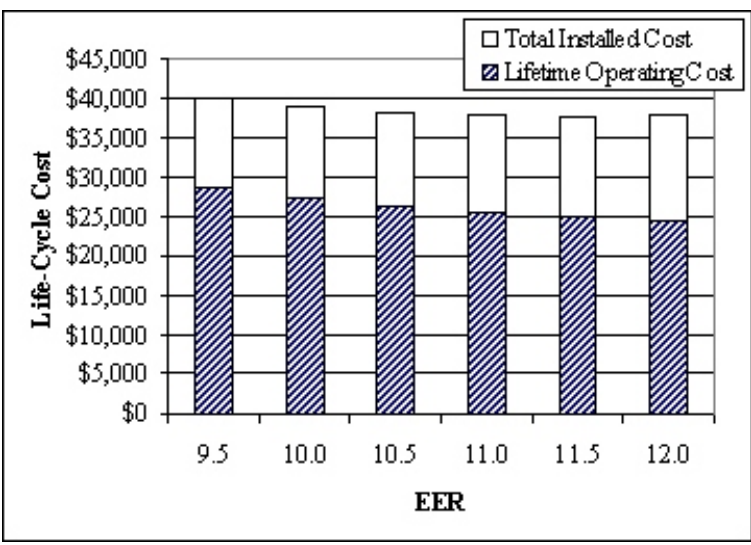

Figure 11

$\geq 135,000 \mathrm{Btu} / \mathrm{h}$ to $<240,000$

Btu/h: Tariff-Based Mean Life-

Cycle Costs 


\subsubsection{Baseline LCC Distributions}

The first step in developing LCC results was to establish the baseline LCC for each of the two commercial air conditioner equipment classes. Figures 12 and 13 show the frequency charts for the baseline LCC for the two equipment classes. A frequency chart shows the distribution of LCCs with the corresponding probability of occurrence. The baseline efficiency level is 10.1 EER for the $\geq 65,000 \mathrm{Btu} / \mathrm{h}$ to $<135,000 \mathrm{Btu} / \mathrm{h}$ air conditioner equipment class, and $9.5 \mathrm{EER}$ for the $\geq 135,000 \mathrm{Btu} / \mathrm{h}$ to $<240,000 \mathrm{Btu} / \mathrm{h}$ equipment class.

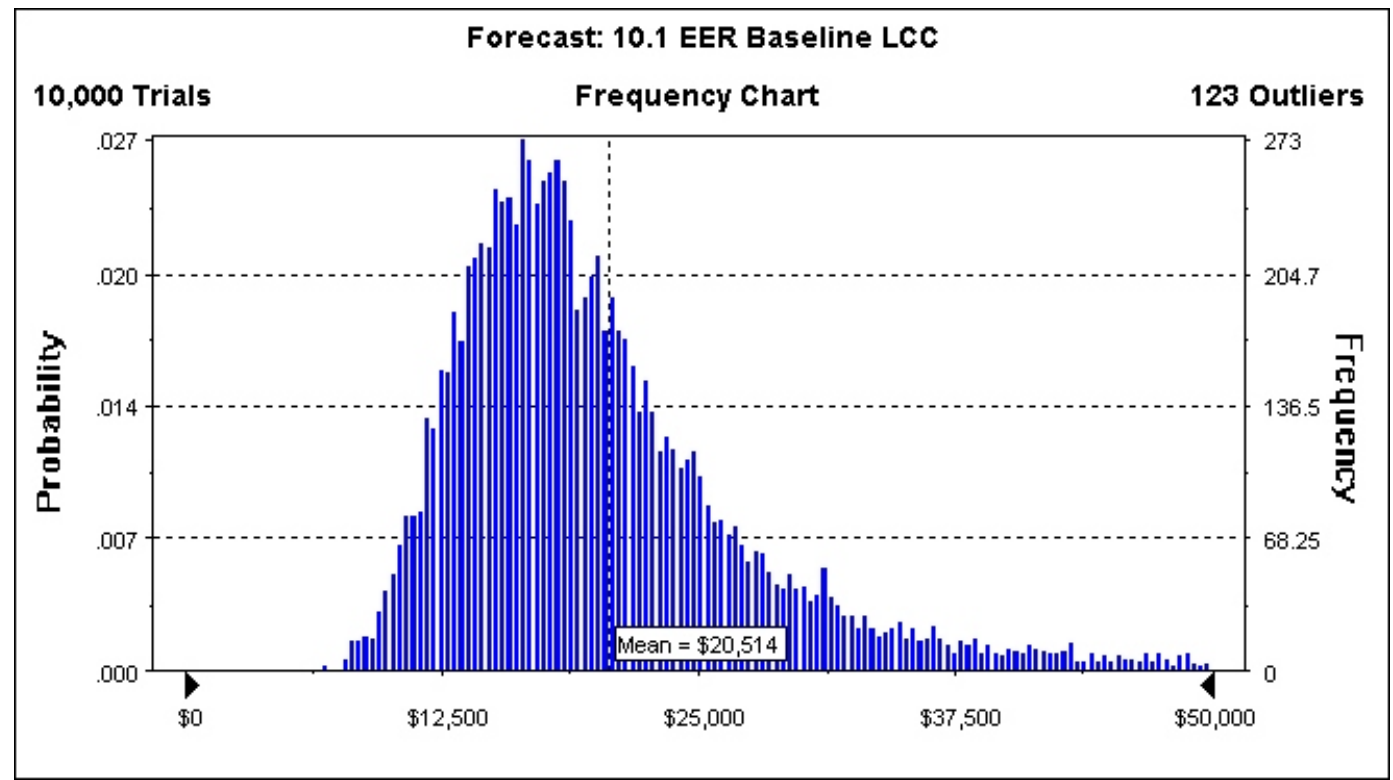

Figure $12 \geq 65,000 \mathrm{Btu} / \mathrm{h}$ to $<135,000 \mathrm{Btu} / \mathrm{h}$ : Tariff-Based Baseline LCC Distribution 


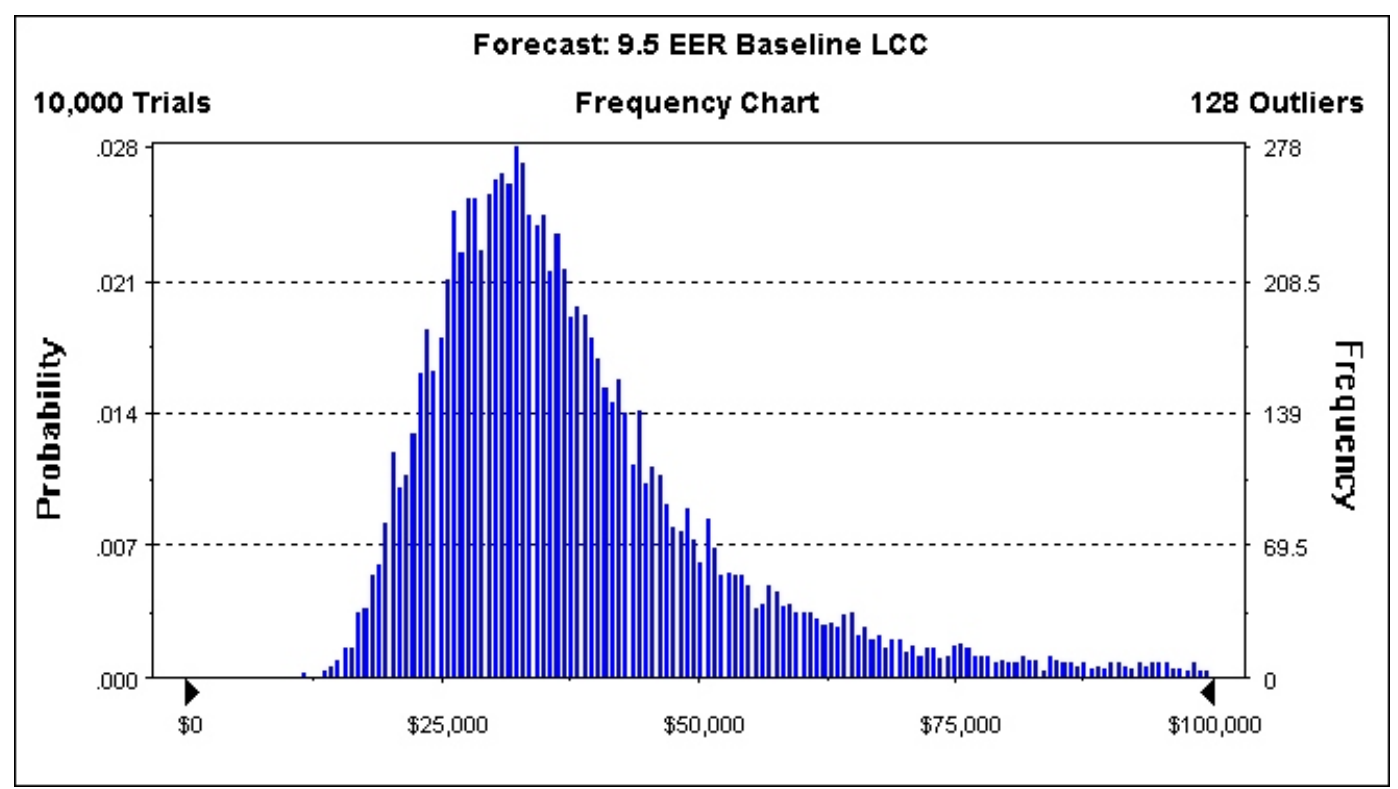

Figure $13 \geq 135,000 \mathrm{Btu} / \mathrm{h}$ to $<240,000 \mathrm{Btu} / \mathrm{h}$ : Tariff-Based Baseline LCC Distribution

\subsubsection{Differences in LCC Between Baseline and Standard EER Level Equipment}

In this section, the differences in the LCC of standard level equipment relative to the baseline design are depicted as a distribution of values. We present the results in frequency charts showing the distribution of LCC differences with the corresponding probability of occurrence. The population is the number of commercial air-conditioning units as opposed to the number of commercial buildings that utilize commercial air-conditioning.

Figure 14 depicts the frequency LCC results for the case of an 11 EER efficiency level for the 65,000 to $135,00 \mathrm{Btu} / \mathrm{h}$ equipment class. The phrase "Certainty is $94.61 \%$ from $\$ 0$ to +Infinity" means that 92.6 percent of commercial air-conditioning units will have LCC savings due to the increased efficiency level (11 EER) compared to the baseline efficiency level (10.1 EER).

The y-axis show the number of commercial air-conditioning units ("Frequency" at right y-axis) and percent of all commercial air-conditioning units ("Probability" at left y-axis). In this 
example, 10,000 units were examined ("10,000 trials") and almost all the results are displayed (except for 8 outliers). The $\mathrm{x}$-axis is the difference in LCC between a baseline efficiency level and a higher efficiency level (in this example, $11 \mathrm{EER}$ ). The $\mathrm{x}$-axis begins with negative values on the left, which indicate that standards for those units increase costs (increased LCC). Moving towards the right on the axis, values greater than zero indicate reductions in LCC (LCC savings). LCC savings occur when increased total installed costs are more than compensated by reductions in operating costs. In Figure 14, going from the baseline efficiency level (10.1 EER) to the 11 EER efficiency level provides commercial air-conditioning units with average LCC savings of $\$ 533$. Changes range from LCC increases of approximately $\$ 325$ (at the left) to LCC savings of approximately $\$ 4400$ (at the right).

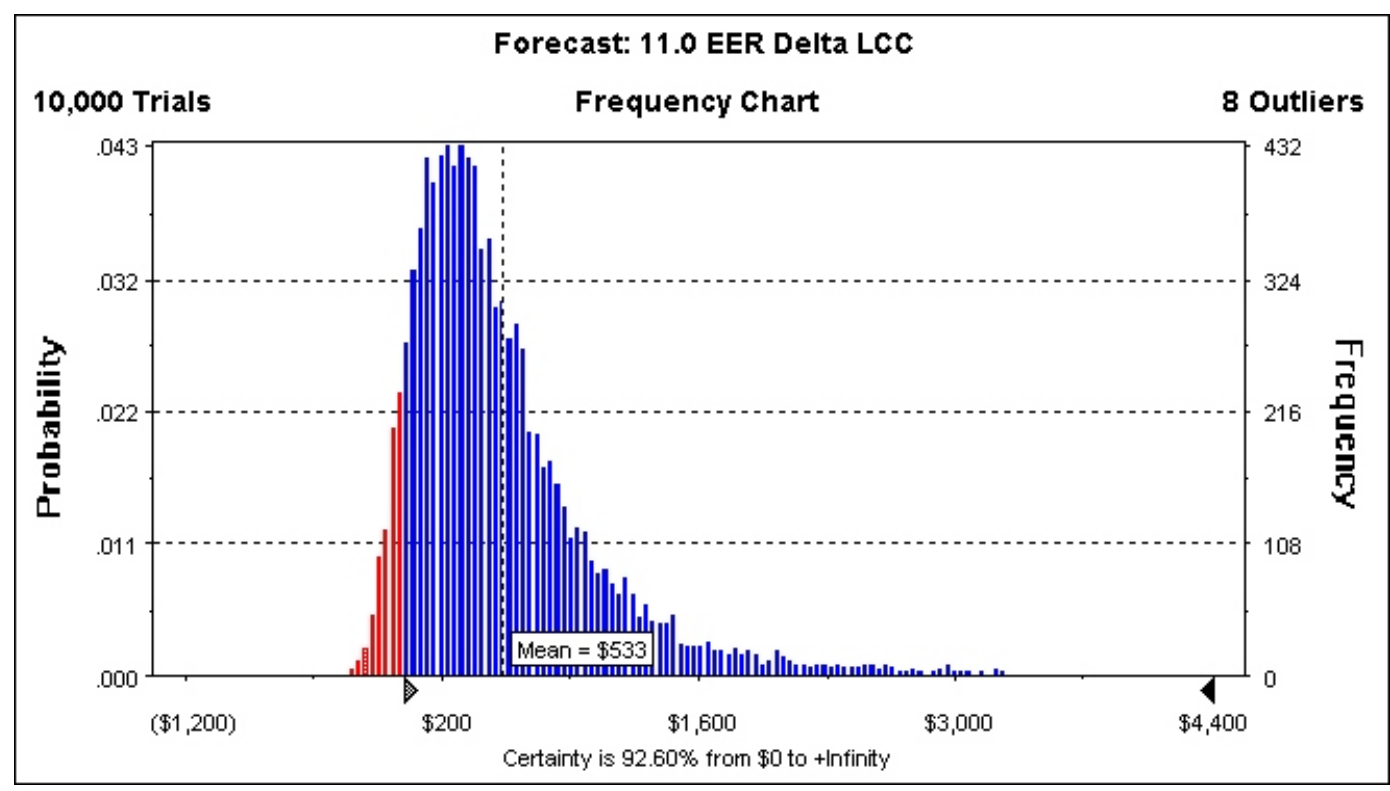

Figure $14 \geq 65,000 \mathrm{Btu} / \mathrm{h}$ to $<135,000 \mathrm{Btu} / \mathrm{h}$ : Tariff-Based Frequency Chart of LCC Differences between 11.0 EER and Baseline (10.1 EER) 
Tables 18 and 19 provide a summary of the change in LCC from the baseline by percentile groupings (i.e., of the distribution of results) for each of the equipment classes. The tables also show the mean and the percent of LCCs that are reduced for each standard EER level.

As an example of how to interpret the information in the tables, consider the 11 EER efficiency level for $\geq 65,000 \mathrm{Btu} / \mathrm{h}$ to $<135,000 \mathrm{Btu} / \mathrm{h}$ commercial air conditioners. The $11 \mathrm{EER}$ efficiency level in Table 18 (row 2) shows that the change in LCC (zero percentile column) is a maximum increase of $\$ 324$. (Negative values are net increases.) For 90 percent of the cases studied $\left(90^{\text {th }}\right.$ percentile), the change in LCC is a reduction of $\$ 1,310$ or less. The largest reduction in LCC is $\$ 7,363\left(100^{\text {th }}\right.$ percentile). The mean change in LCC is a net savings of $\$ 609$. The last column shows that 95 percent of the sample have LCC savings (i.e., reductions in LCC greater than zero).

Table 18 Summary of Tariff-Based LCC Results for $\geq 65,000 \mathrm{Btu} / \mathrm{h}$ to $<135,000 \mathrm{Btu} / \mathrm{h}$ Commercial Air Conditioners

\begin{tabular}{|c|c|c|c|c|c|c|c|c|c|c|c|c|c|}
\hline \multirow[t]{2}{*}{ EER } & \multicolumn{12}{|c|}{$\begin{array}{c}\text { Decrease in LCC from Baseline (10.1 EER) Shown by Percentiles of the Distribution of } \\
\text { Results (2001\$) }\end{array}$} & \multirow{2}{*}{$\begin{array}{l}\text { Percent } \\
\text { of Units } \\
\text { with } \\
\text { LCC } \\
\text { Savings }\end{array}$} \\
\hline & $0 \%$ & $10 \%$ & $20 \%$ & $30 \%$ & $40 \%$ & $50 \%$ & $60 \%$ & $70 \%$ & $80 \%$ & $90 \%$ & $100 \%$ & Mean & \\
\hline 10.5 & $(\$ 100)$ & $\$ 55$ & $\$ 105$ & $\$ 143$ & $\$ 185$ & $\$ 228$ & $\$ 276$ & $\$ 338$ & $\$ 424$ & $\$ 587$ & $\$ 2,798$ & $\$ 290$ & $98 \%$ \\
\hline 11.0 & (\$333) & $\$ 31$ & $\$ 132$ & $\$ 222$ & $\$ 311$ & $\$ 398$ & $\$ 505$ & $\$ 635$ & $\$ 823$ & $\$ 1,181$ & $\$ 5,764$ & $\$ 533$ & $93 \%$ \\
\hline 11.5 & $(\$ 745)$ & $(\$ 143)$ & $\$ 11$ & $\$ 144$ & $\$ 273$ & $\$ 401$ & $\$ 550$ & $\$ 753$ & $\$ 1,032$ & $\$ 1,543$ & $\$ 8,356$ & $\$ 598$ & $81 \%$ \\
\hline 12.0 & $(\$ 1,606)$ & $(\$ 567)$ & (\$360) & $(\$ 183)$ & $(\$ 27)$ & $\$ 153$ & $\$ 349$ & $\$ 601$ & $\$ 968$ & $\$ 1,606$ & $\$ 10,273$ & $\$ 399$ & $59 \%$ \\
\hline
\end{tabular}

Table 19 Summary of Tariff-Based LCC Results for $\geq 135,000 \mathrm{Btu} / \mathrm{h}$ to $<240,000 \mathrm{Btu} / \mathrm{h}$ Commercial Air Conditioners

\begin{tabular}{|c|c|c|c|c|c|c|c|c|c|c|c|c|c|}
\hline \multirow[t]{2}{*}{ EER } & \multicolumn{3}{|c|}{ Decrease in $\mathrm{LCC}$ from } & \multicolumn{4}{|c|}{ 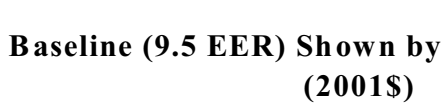 } & \multicolumn{5}{|c|}{ Percentiles of the Distribution of Results } & \multirow{2}{*}{$\begin{array}{c}\text { Percent } \\
\text { of Units } \\
\text { with } \\
\text { LCC } \\
\text { Savings }\end{array}$} \\
\hline & $0 \%$ & $10 \%$ & $20 \%$ & $30 \%$ & $40 \%$ & $50 \%$ & $60 \%$ & $70 \%$ & $80 \%$ & $90 \%$ & $100 \%$ & Mean & \\
\hline 10.0 & $(\$ 180)$ & $\$ 283$ & $\$ 481$ & $\$ 422$ & $\$ 537$ & $\$ 655$ & $\$ 915$ & $\$ 1,090$ & $\$ 1,340$ & $\$ 1,817$ & & $\$ 959$ & $100 \%$ \\
\hline 10.5 & $(\$ 409)$ & $\$ 432$ & $\$ 696$ & $\$ 910$ & $\$ 1,128$ & $\$ 1,363$ & $\$ 1,619$ & $\$ 1,958$ & $\$ 2,428$ & $\$ 3,340$ & $\$ 15,472$ & $\$ 1,704$ & $99 \%$ \\
\hline 11.0 & $(\$ 1,058)$ & $\$ 376$ & $\$ 759$ & $\$ 1,08$ & $\$ 1,397$ & $\$ 1,712$ & $\$ 2,088$ & $\$ 2,540$ & $\$ 3,223$ & $\$ 4,518$ & $\$ 21,997$ & $\$ 2,199$ & $97 \%$ \\
\hline 11.5 & $(\$ 1,944)$ & $\$ 41$ & $\$ 531$ & $\$ 928$ & $\$ 1,331$ & $\$ 1,744$ & $\$ 2,214$ & $\$ 2,821$ & $\$ 3,670$ & $\$ 5,312$ & $\$ 27,235$ & $\$ 2,359$ & $91 \%$ \\
\hline 12.0 & $(\$ 3,647)$ & $(\$ 794)$ & $(\$ 181)$ & $\$ 330$ & $\$ 825$ & $\$ 1,365$ & $\$ 1,942$ & $\$ 2,634$ & $\$ 3,621$ & $\$ 5,504$ & $\$ 30,431$ & $\$ 2,027$ & $77 \%$ \\
\hline
\end{tabular}




\subsection{PBP Results}

This section presents PBP results for the efficiency improvement levels that are based on annual operating costs calculated from tariff-based electricity prices. Similar to the LCC results, we depict PBP results as a distribution of values. Thus, we present the results as a frequency chart showing the distribution of PBPs with the corresponding probability of occurrence.

Figure 15 is a frequency chart showing the distribution of payback periods for the 11 EER efficiency level for the $\geq 65,000 \mathrm{Btu} / \mathrm{h}$ to $<135,000 \mathrm{Btu} / \mathrm{h}$ commercial air conditioner equipment class. The chart is the result of 10,000 Monte Carlo simulation runs.

In Figure 15, the y-axis shows the number of commercial air-conditioning units ("Frequency" at right y-axis) and percent of all commercial air-conditioning units ("Probability" at left y-axis). In this example, 10,000 units were examined ("10,000 trials") and almost all the results are displayed (except 15 outliers). The $\mathrm{x}$-axis is the PBP of a higher efficiency level (in this example, 11 EER) relative to the baseline efficiency level (10.1 EER). An 11 EER efficiency level provides commercial air-conditioning units with an average PBP of 3.5 years. The PBP ranges from just greater than 0 years to approximately 20 years depending upon the unit.

Tables 20 and 21 summarize the PBP results for each of the two commercial air conditioner equipment classes.

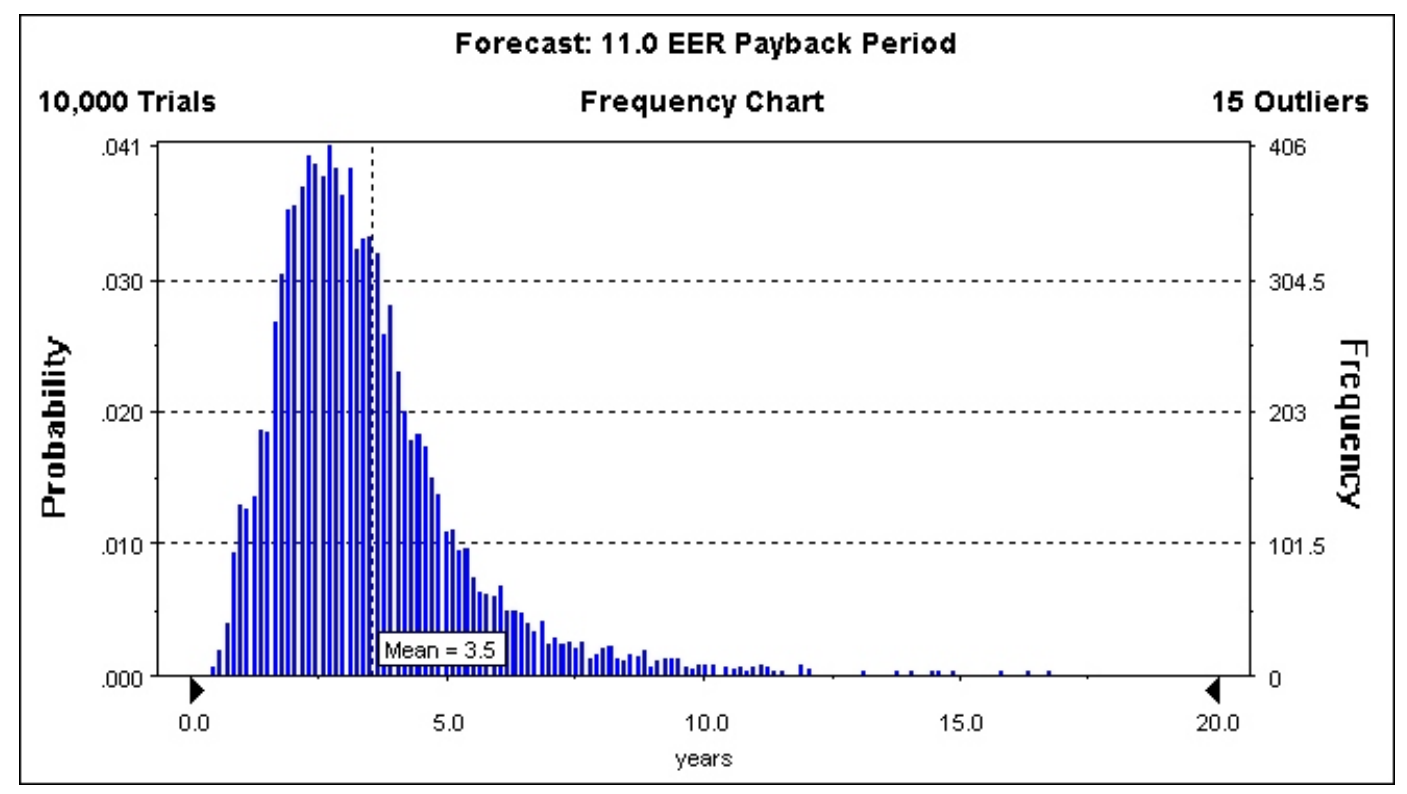

Figure $15 \geq 65,000 \mathrm{Btu} / \mathrm{h}$ to $<135,000 \mathrm{Btu} / \mathrm{h}$ : Tariff-Based Frequency Chart of Payback Periods for 11 EER 
Table 20 Summary of Tariff-Based PBP Results for $\geq 65,000 \mathrm{Btu} / \mathrm{h}$ to $<135,000 \mathrm{Btu} / \mathrm{h}$ Commercial Air Conditioners

\begin{tabular}{c|cccccccccccc}
\hline & \multicolumn{8}{|c}{ Payback Period in Years Show n by Percentiles of the Distribution of Results } \\
EER & $0 \%$ & $10 \%$ & $20 \%$ & $30 \%$ & $40 \%$ & $50 \%$ & $60 \%$ & $70 \%$ & $80 \%$ & $90 \%$ & $100 \%$ & Mean \\
\hline 10.5 & 0.3 & 1.2 & 1.6 & 1.8 & 2.1 & 2.3 & 2.6 & 2.9 & 3.3 & 4.1 & 25 & 2.6 \\
11.0 & 0.4 & 1.6 & 2.0 & 2.4 & 2.7 & 3.1 & 3.5 & 3.9 & 4.5 & 5.7 & 65 & 3.5 \\
11.5 & 0.6 & 2.2 & 2.8 & 3.3 & 3.8 & 4.3 & 4.9 & 5.6 & 6.5 & 8.3 & $>100$ & 5.1 \\
12.0 & 0.8 & 3.1 & 4.0 & 4.8 & 5.6 & 6.4 & 7.4 & 8.5 & 10 & 14 & $>100$ & 8.1 \\
\hline
\end{tabular}

Table 21 Summary of Tariff-Based PBP Results for $\geq 135,000 \mathrm{Btu} / \mathrm{h}$ to $<240,000 \mathrm{Btu} / \mathrm{h}$ Commercial Air Conditioners

\begin{tabular}{c|ccccccccccccc}
\hline & \multicolumn{8}{|c}{ Payback Period in Years Shown by Percentiles of the Distribution of Results } \\
EER & $0 \%$ & $10 \%$ & $20 \%$ & $30 \%$ & $40 \%$ & $50 \%$ & $60 \%$ & $70 \%$ & $80 \%$ & $90 \%$ & $100 \%$ & Mean \\
\hline 10.0 & 0.3 & 0.8 & 1.0 & 1.2 & 1.3 & 1.5 & 1.6 & 1.8 & 2.1 & 2.6 & 15 & 1.6 \\
10.5 & 0.3 & 1.0 & 1.2 & 1.4 & 1.6 & 1.8 & 2.1 & 2.3 & 2.7 & 3.3 & 20 & 2.0 \\
11.0 & 0.4 & 1.2 & 1.6 & 1.8 & 2.1 & 2.4 & 2.7 & 3.0 & 3.5 & 4.4 & 46 & 2.7 \\
11.5 & 0.4 & 1.6 & 2.0 & 2.4 & 2.8 & 3.2 & 3.6 & 4.2 & 4.9 & 6.2 & 86 & 3.7 \\
12.0 & 0.5 & 2.2 & 2.8 & 3.4 & 3.9 & 4.5 & 5.2 & 6.1 & 7.3 & 10 & $>100$ & 5.5 \\
\hline
\end{tabular}

\section{RESULTS USING HOURLY-BASED ELECTRICITY PRICES}

\subsection{LCC Results}

This section presents LCC results based on annual operating costs calculated from hourlybased electricity prices. As with the LCC results based on tariff-based electricity prices, we represent LCC results based on hourly electricity prices as a distribution of values.

\subsubsection{LCC Breakdown Based upon Average Input Values}

For each equipment class, Figures 16 through 21 show how, on an average basis, the total installed costs, annual operating costs, and LCC vary with efficiency.

We segmented total installed cost into equipment price and installation cost, and we segmented annual operating cost into annual electricity, repair, and maintenance costs. For LCC 
the figures are segmented into total installed cost and lifetime operating cost. Although the following figures are based on mean or average values rather than results from the Monte Carlo simulation analysis, they serve to demonstrate how the various inputs ultimately impact LCC.

In reviewing the total installed cost results for either equipment class, the largest contributor to increased total installed cost is the equipment price since the installation cost remains relatively constant across efficiency. With regard to annual operating cost, the hourlybased results reveal similar results to the tariff-based analytic results, namely, that the largest contributor to the overall operating cost at any efficiency level is the annual electricity cost. As efficiency increases, the electricity cost decreases. Even at the maximum efficiency level (12 EER), the drop in the annual electricity cost more than offsets the relatively small increase in repair costs. Note that because the maintenance cost is assumed to remain constant across all efficiency levels, it does not contribute to the change in the overall annual operating cost as efficiency increases.

The hourly-based LCC results reveal the same observations as for the tariff-based results. As efficiency increases, the lifetime operating cost has more of an impact on the LCC than the total installed cost. In other words, the increase in total installed cost that occurs when equipment efficiency is increased is offset by the decrease in lifetime operating costs. As a result, the LCC at all efficiency levels is lower than that for the baseline level. As with the tariff-based results, the minimum hourly-based LCC occurs at an efficiency of 11.5 EER for both commercial air conditioner equipment classes. For efficiencies beyond 11.5 EER, the incremental decrease in lifetime operating costs is offset by the incremental increase in total installed costs.

It is worth reiterating that the results shown in Figures 16 through 21 are based upon average input values rather than input distributions. Thus, although one can observe how the various inputs impact life-cycle cost and, in turn, how the resulting life-cycle costs change with efficiency, one should only draw conclusions from the distribution of life-cycle cost results that are presented in Section 5.1.3. 


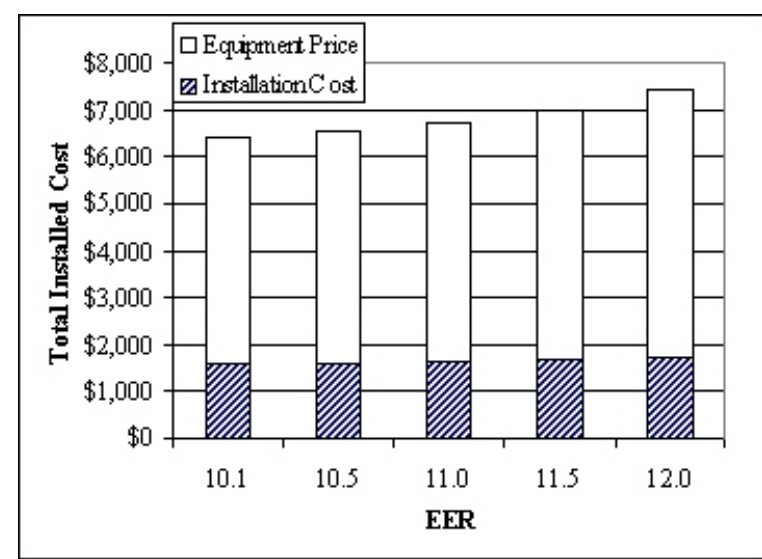

Figure 16 $\geq 65,000 \mathrm{Btu} / \mathrm{h}$ to $<135,000 \mathrm{Btu} / \mathrm{h}$ : Mean Total Installed Costs

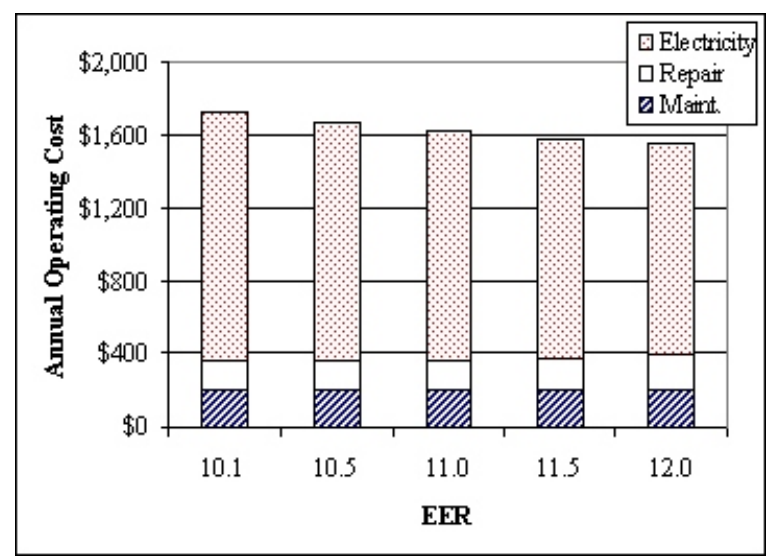

Figure $18 \geq 65,000 \mathrm{Btu} / \mathrm{h}$ to $<135,000 \mathrm{Btu} / \mathrm{h}$ : Hourly-Based Mean Annual Operating Costs

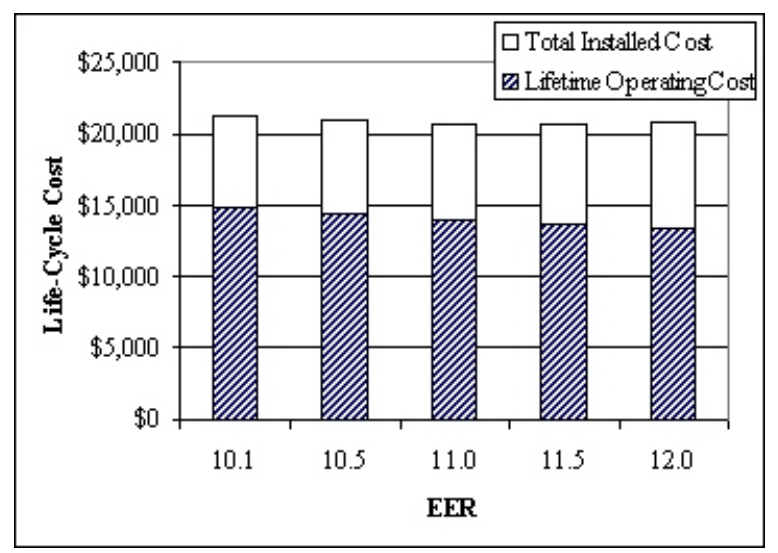

Figure 20 $\geq 65,000 \mathrm{Btu} / \mathrm{h}$ to $<135,000 \mathrm{Btu} / \mathrm{h}$ : Hourly-Based Mean Life-Cycle Costs

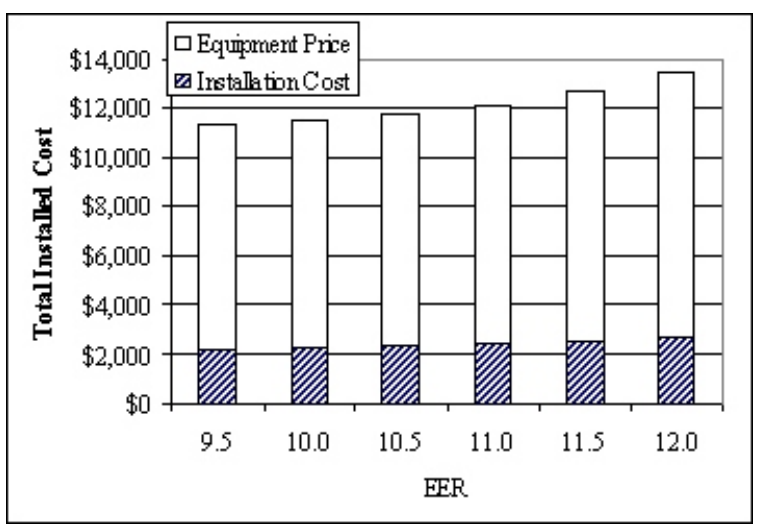

Figure $17 \geq 135,000 \mathrm{Btu} / \mathrm{h}$ to $<240,000$ Btu/h: Mean Total Installed Costs

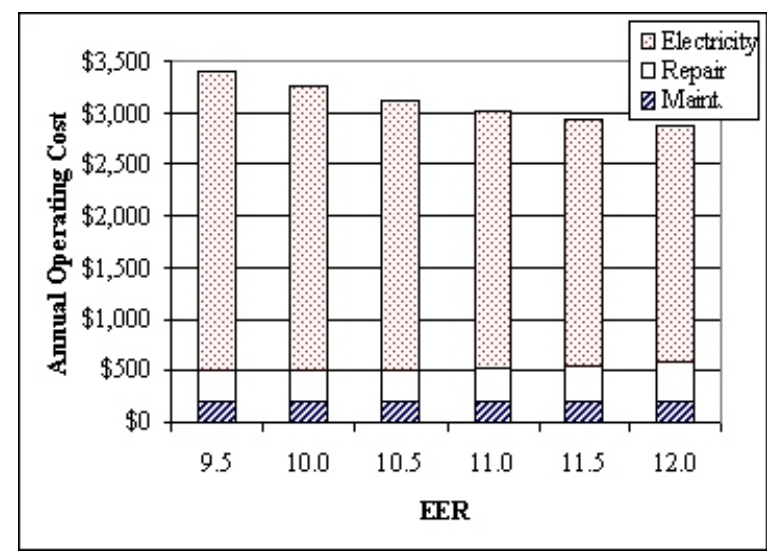

Figure $19 \geq 135,000 \mathrm{Btu} / \mathrm{h}$ to $<240,000$ Btu/h: Hourly-Based Mean Annual Operating Costs

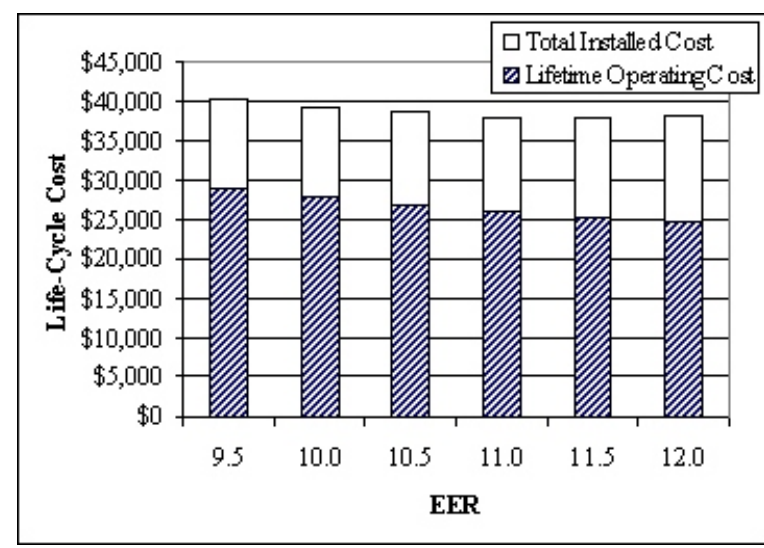

Figure 21

$\geq 135,000 \mathrm{Btu} / \mathrm{h}$ to $<240,000$ Btu/h: Hourly-Based Mean LifeCycle Costs 


\subsubsection{Baseline LCC Distributions}

We used the Monte Carlo simulation method of analysis, to conduct the LCC analysis. The results presented here are based on 10,000 samples per Monte Carlo simulation run.

As stated earlier, the first step in developing LCC results was to establish the baseline LCC for each of the two commercial air conditioner equipment classes. Figures 22 and 23 show the frequency charts for the hourly-based baseline LCC for the two equipment classes. The baseline efficiency level is 10.1 EER for the $\geq 65,000 \mathrm{Btu} / \mathrm{h}$ to $<135,000 \mathrm{Btu} / \mathrm{h}$ air conditioner equipment class, and 9.5 EER for the $\geq 135,000 \mathrm{Btu} / \mathrm{h}$ to $<240,000 \mathrm{Btu} / \mathrm{h}$ equipment class. Note that although the hourly-based baseline LCCs have nearly the same mean and median values as those from the tariff-based baseline LCCs, the range of baseline LCCs is smaller than the tariffbased values.

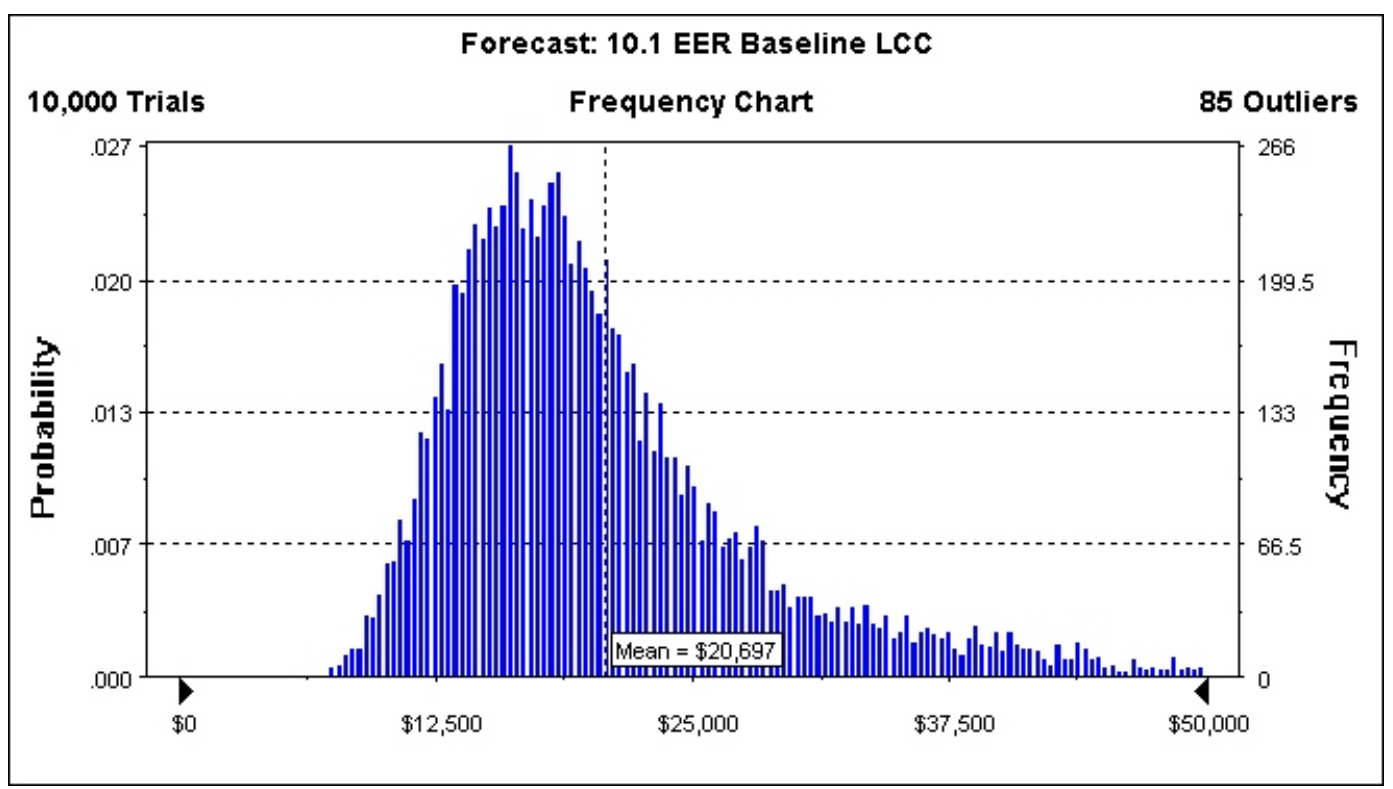

Figure $22 \quad \geq 65,000 \mathrm{Btu} / \mathrm{h}$ to $<135,000 \mathrm{Btu} / \mathrm{h}$ : Hourly-Based Baseline (10.1 EER) LCC Distribution 


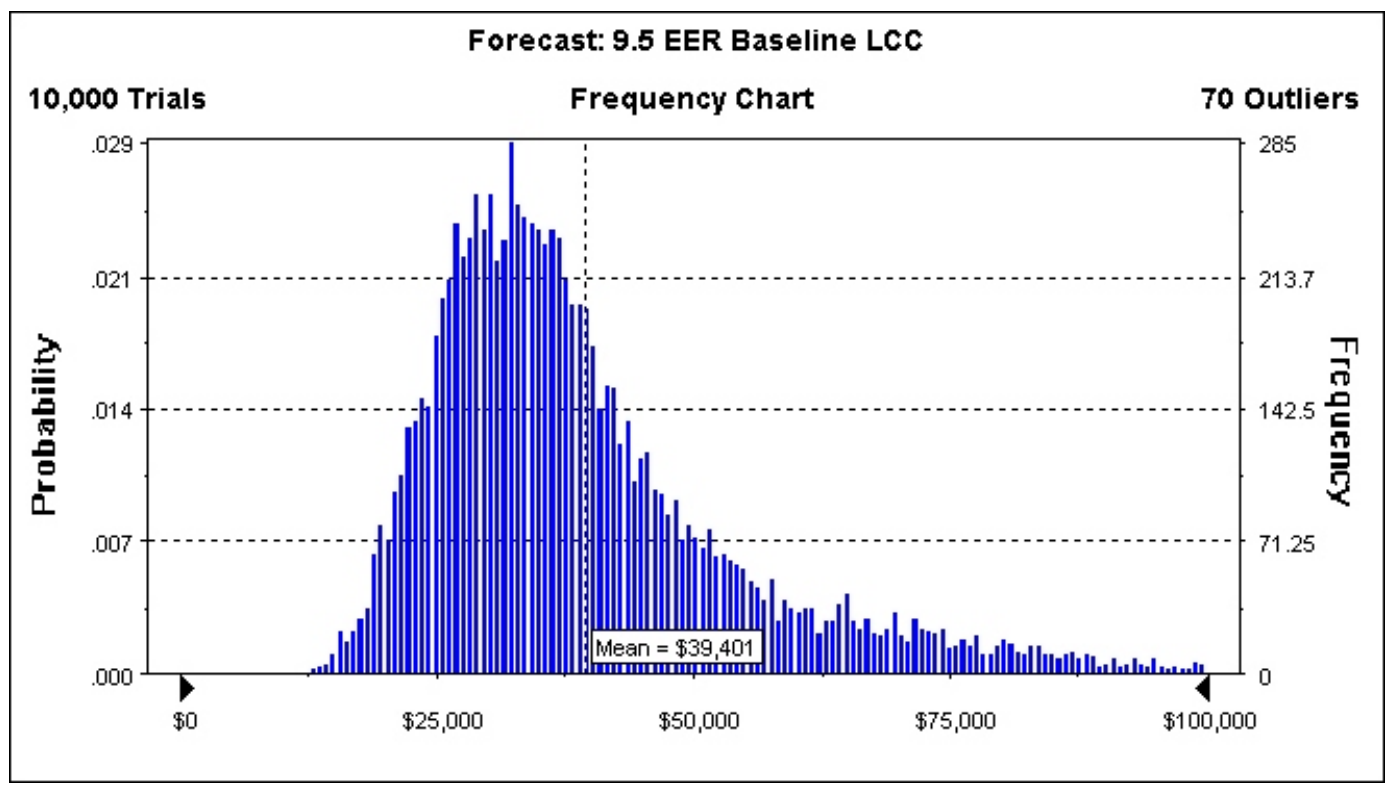

Figure $23 \quad \geq 135,000 \mathrm{Btu} / \mathrm{h}$ to $<240,000 \mathrm{Btu} / \mathrm{h}$ : Hourly-Based Baseline $(9.5$ EER) LCC Distribution

\subsubsection{Differences in LCC Between Baseline and Standard EER Level Equipment}

This section presents the differences in the LCC of standard EER level equipment relative to the baseline EER commercial air conditioner design as a distribution of values. The results are presented in a frequency chart showing the distribution of LCC differences with its corresponding probability of occurrence and 2) a cumulative chart showing the cumulative distribution of LCC differences along with the corresponding probability of occurrence. The population is the number of commercial air-conditioning units as opposed to the number of commercial buildings that utilize commercial air-conditioning.

Tables 22 and 23 provide a summary of the change in LCC from the baseline EER by percentile groupings (i.e., of the distribution of results) for each of the equipment classes as well as the mean and the percent of LCCs that are reduced for each standard EER level.

The hourly-based mean LCC savings at each efficiency level are virtually the same as those from the tariff-based analysis. On the other hand, the percentage of units with LCC savings 
under the hourly-based analysis is slightly greater at each efficiency level than for the tariff-based analysis. These results indicate that the range of electricity prices realized from the hourly-based analysis is lower than that from the tariff-based analysis. As a result, using the hourly-based prices eliminates the extreme electricity price cases present under the tariff-based analysis that result in units achieving either large LCC increases or large LCC savings. Because units with extreme LCC increases are eliminated from the hourly-based analysis, there are fewer units faced with LCC increases and as a result, there are more units achieving LCC savings at each efficiency level.

Table 22 Summary of Hourly-Based LCC Results for $\geq 65,000 \mathrm{Btu} / \mathrm{h}$ to $<135,000 \mathrm{Btu} / \mathrm{h}$ Commercial Air Conditioners

\begin{tabular}{c|cccccccccccc|c}
\hline \multirow{2}{*}{ EER } & \multicolumn{10}{|c|}{ Decrease in LCC from Baseline (10.1 EER) Shown by Percentiles of the Distribution of } \\
Results (2001\$) & $\begin{array}{l}\text { Percent } \\
\text { of Units } \\
\text { with } \\
\text { LCC } \\
\text { Savings }\end{array}$ \\
\hline 10.5 & $0 \%$ & $10 \%$ & $20 \%$ & $30 \%$ & $40 \%$ & $50 \%$ & $60 \%$ & $70 \%$ & $80 \%$ & $90 \%$ & $100 \%$ & Mean \\
11.0 & $(\$ 234)$ & $\$ 98$ & $\$ 149$ & $\$ 189$ & $\$ 227$ & $\$ 263$ & $\$ 304$ & $\$ 354$ & $\$ 424$ & $\$ 534$ & $\$ 1,373$ & $\$ 293$ & $99 \%$ \\
11.5 & $(\$ 530)$ & $\$ 8$ & $\$ 166$ & $\$ 285$ & $\$ 402$ & $\$ 511$ & $\$ 641$ & $\$ 795$ & $\$ 1,019$ & $\$ 1,360$ & $\$ 3,842$ & $\$ 610$ & $90 \%$ \\
12.0 & $(\$ 104)$ & $\$ 354)$ & $(\$ 154)$ & $(\$ 1)$ & $\$ 144$ & $\$ 287$ & $\$ 448$ & $\$ 647$ & $\$ 931$ & $\$ 1,372$ & $\$ 4,364$ & $\$ 414$ & $70 \%$ \\
\hline
\end{tabular}

Table 23 Summary of Hourly-Based LCC Results for $\geq 135,000 \mathrm{Btu} / \mathrm{h}$ to $<240,000 \mathrm{Btu} / \mathrm{h}$ Commercial Air Conditioners

\begin{tabular}{|c|c|c|c|c|c|c|c|c|c|c|c|c|c|}
\hline \multirow[t]{2}{*}{ EER } & \multicolumn{3}{|c|}{ Decrease in LCC from } & \multicolumn{4}{|c|}{$\begin{array}{l}\text { B aseline (9.5 EER) Shown by } \\
\text { (2001\$) }\end{array}$} & \multicolumn{5}{|c|}{ Percentiles of the Distribution of Results } & \multirow{2}{*}{$\begin{array}{c}\text { Percent } \\
\text { of Units } \\
\text { with } \\
\text { LCC } \\
\text { Savings }\end{array}$} \\
\hline & $0 \%$ & $10 \%$ & $20 \%$ & $30 \%$ & $40 \%$ & $50 \%$ & $60 \%$ & $70 \%$ & $80 \%$ & $90 \%$ & $100 \%$ & Mean & \\
\hline 10.0 & $(\$ 60)$ & $\$ 403$ & $\$ 552$ & $\$ 665$ & $\$ 773$ & $\$ 882$ & $\$ 999$ & $\$ 1,141$ & $\$ 1,329$ & $\$ 1,655$ & $\$ 4,560$ & $\$ 967$ & $100 \%$ \\
\hline 10.5 & $(\$ 209)$ & $\$ 658$ & $\$ 934$ & $\$ 1,147$ & $\$ 1,352$ & $\$ 1,557$ & $\$ 1,781$ & $\$ 2,046$ & $\$ 2,402$ & $\$ 3,014$ & $\$ 8,489$ & $\$ 1,718$ & $100 \%$ \\
\hline 11.0 & $(\$ 490)$ & $\$ 728$ & $\$ 1,108$ & $\$ 1,410$ & $\$ 1,699$ & $\$ 1,984$ & $\$ 2,310$ & $\$ 2,684$ & $\$ 3,193$ & $\$ 4,067$ & $\$ 11,816$ & $\$ 2,222$ & $99 \%$ \\
\hline 11.5 & $(\$ 983)$ & $\$ 515$ & $\$ 995$ & $\$ 1,364$ & $\$ 1,725$ & $\$ 2,080$ & $\$ 2,494$ & $\$ 2,970$ & $\$ 3,610$ & $\$ 4,716$ & $\$ 14,436$ & $\$ 2,390$ & $97 \%$ \\
\hline 12.0 & $(\$ 1,840)$ & $(\$ 12$ & $\$ 426$ & $\$ 861$ & $\$ 1,281$ & $\$ 1,695$ & $\$ 2,177$ & $\$ 2,741$ & $\$ 3,512$ & $\$ 4,794$ & $\$ 16,156$ & $\$ 2,067$ & $89 \%$ \\
\hline
\end{tabular}

\subsection{PBP Results}

This section presents PBP results for the efficiency improvement levels. The results are based on annual operating costs calculated from hourly-based electricity prices. Similar to the LCC differences, the results are presented as a frequency chart showing the distribution of PBPs with corresponding probability of occurrence. Refer to Section 4.2 on the tariff-based PBPs for a description of how to interpret the PBP frequency charts. 
Figure 24 shows the PBP results for the $\geq 65,000 \mathrm{Btu} / \mathrm{h}$ to $<135,000 \mathrm{Btu} / \mathrm{h}$ equipment class at 11 EER. Note the bi-modal nature of the frequency chart. This bi-modal nature is common to all the hourly PBP distributions. The bi-modal nature is due to the annual energy expense portion of the PBP calculation. Figure 25 shows the distribution of annual electricity expense differences between 11 EER and the baseline (10.1 EER). As indicated by the figure, the annual energy expense differences are distributed relatively unevenly (i.e., expenses are not smoothly distributed). The uneven nature of the distribution is due to the hourly electricity price component of the energy expense. Hourly electricity prices vary in a semi-discontinuous manner around the nation (i.e., there are relatively few hourly prices around the price distribution average which, therefore, results in a bi-modal distribution). Thus, the energy expenses also vary in a bi-modal fashion. Because the energy expense difference is a primary component to the PBP, the PBP distributions are also bi-modal.

Tables 24 and 25 summarize the hourly-based PBP results for each of the two commercial air conditioner equipment classes.

Table 24 Summary of Hourly-Based PBP Results for $\geq 65,000 \mathrm{Btu} / \mathrm{h}$ to $<135,000 \mathrm{Btu} / \mathrm{h}$ Commercial Air Conditioners

\begin{tabular}{c|ccccccccccccc}
\hline & \multicolumn{8}{|c}{ Payback Period in Years Shown by Percentiles of the Distribution of Results } \\
EER & $0 \%$ & $10 \%$ & $20 \%$ & $30 \%$ & $40 \%$ & $50 \%$ & $60 \%$ & $70 \%$ & $80 \%$ & $90 \%$ & $100 \%$ & Mean \\
\hline 10.5 & 0.8 & 1.3 & 1.5 & 1.7 & 2.0 & 2.2 & 2.4 & 2.6 & 2.8 & 3.1 & 7.0 & 2.2 \\
11.0 & 1.1 & 1.7 & 2.0 & 2.3 & 2.7 & 2.9 & 3.2 & 3.4 & 3.7 & 4.2 & 10 & 3.0 \\
11.5 & 1.5 & 2.3 & 2.7 & 3.2 & 3.7 & 4.1 & 4.4 & 4.7 & 5.2 & 5.9 & 17 & 4.2 \\
12.0 & 2.1 & 3.4 & 4.0 & 4.7 & 5.4 & 6.0 & 6.5 & 7.0 & 7.8 & 9.0 & 35 & 6.2 \\
\hline
\end{tabular}

Table 25 Summary of Hourly-Based PBP Results for $\geq 135,000$ Btu/h to $<240,000$ Btu/h Commercial Air Conditioners

\begin{tabular}{c|ccccccccccccc}
\hline & \multicolumn{8}{|c}{ Payback Period in Years Show n by Percentiles of the Distribution of Results } \\
EER & $0 \%$ & $10 \%$ & $20 \%$ & $30 \%$ & $40 \%$ & $50 \%$ & $60 \%$ & $70 \%$ & $80 \%$ & $90 \%$ & $100 \%$ & Mean \\
\hline 10.0 & 0.5 & 0.8 & 0.9 & 1.1 & 1.3 & 1.4 & 1.6 & 1.7 & 1.9 & 2.1 & 5.3 & 1.4 \\
10.5 & 0.6 & 1.0 & 1.1 & 1.4 & 1.6 & 1.8 & 1.9 & 2.1 & 2.3 & 2.6 & 6.8 & 1.8 \\
11.0 & 0.8 & 1.3 & 1.5 & 1.8 & 2.1 & 2.3 & 2.5 & 2.7 & 3.0 & 3.3 & 9.3 & 2.3 \\
11.5 & 1.1 & 1.7 & 2.0 & 2.4 & 2.8 & 3.1 & 3.3 & 3.6 & 3.9 & 4.4 & 14 & 3.1 \\
12.0 & 1.6 & 2.5 & 2.9 & 3.4 & 4.0 & 4.4 & 4.7 & 5.1 & 5.6 & 6.4 & 24 & 4.5 \\
\hline
\end{tabular}




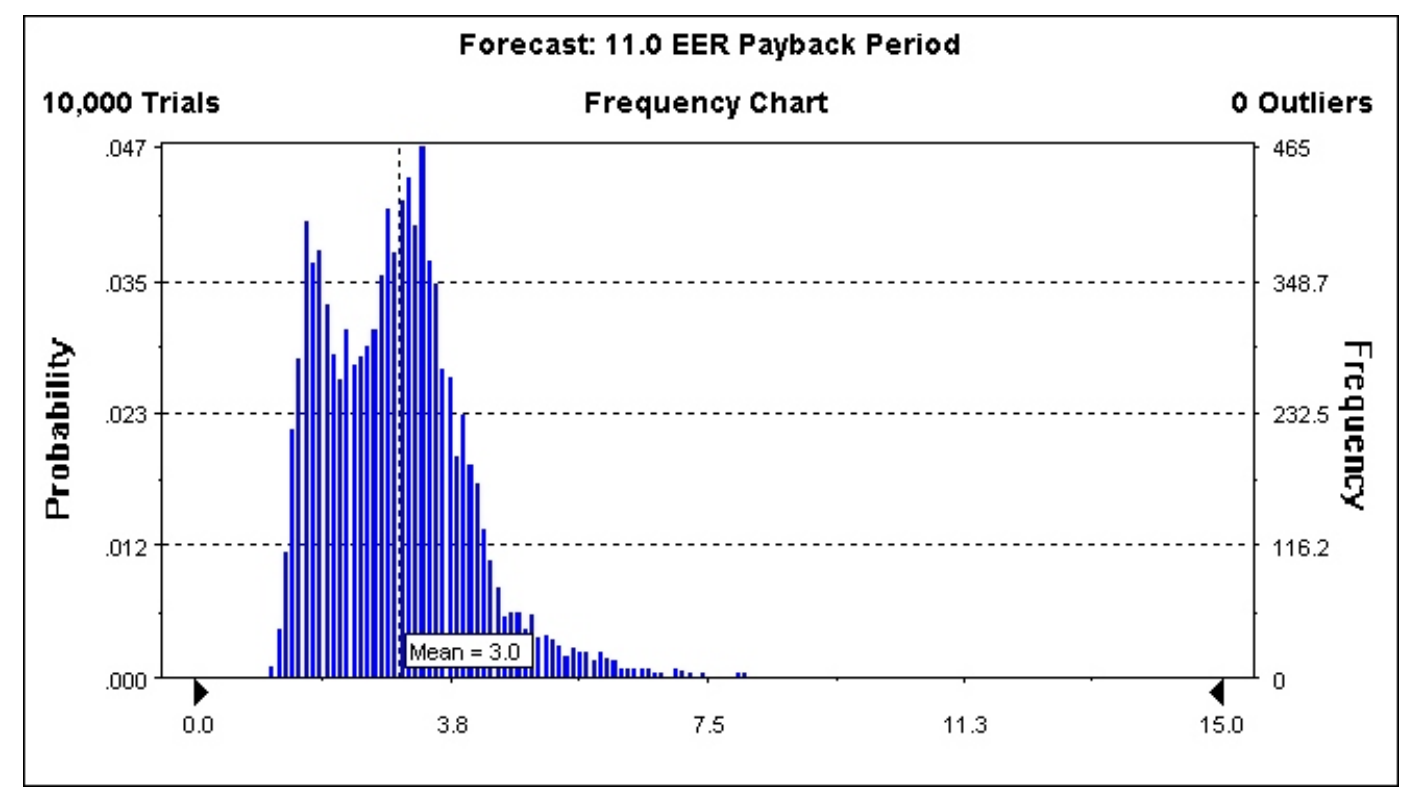

Figure $24 \geq 65,000 \mathrm{Btu} / \mathrm{h}$ to $<\mathbf{1 3 5 , 0 0 0} \mathrm{Btu} / \mathrm{h}$ : Hourly-Based Frequency Chart of Payback Periods for 11 EER

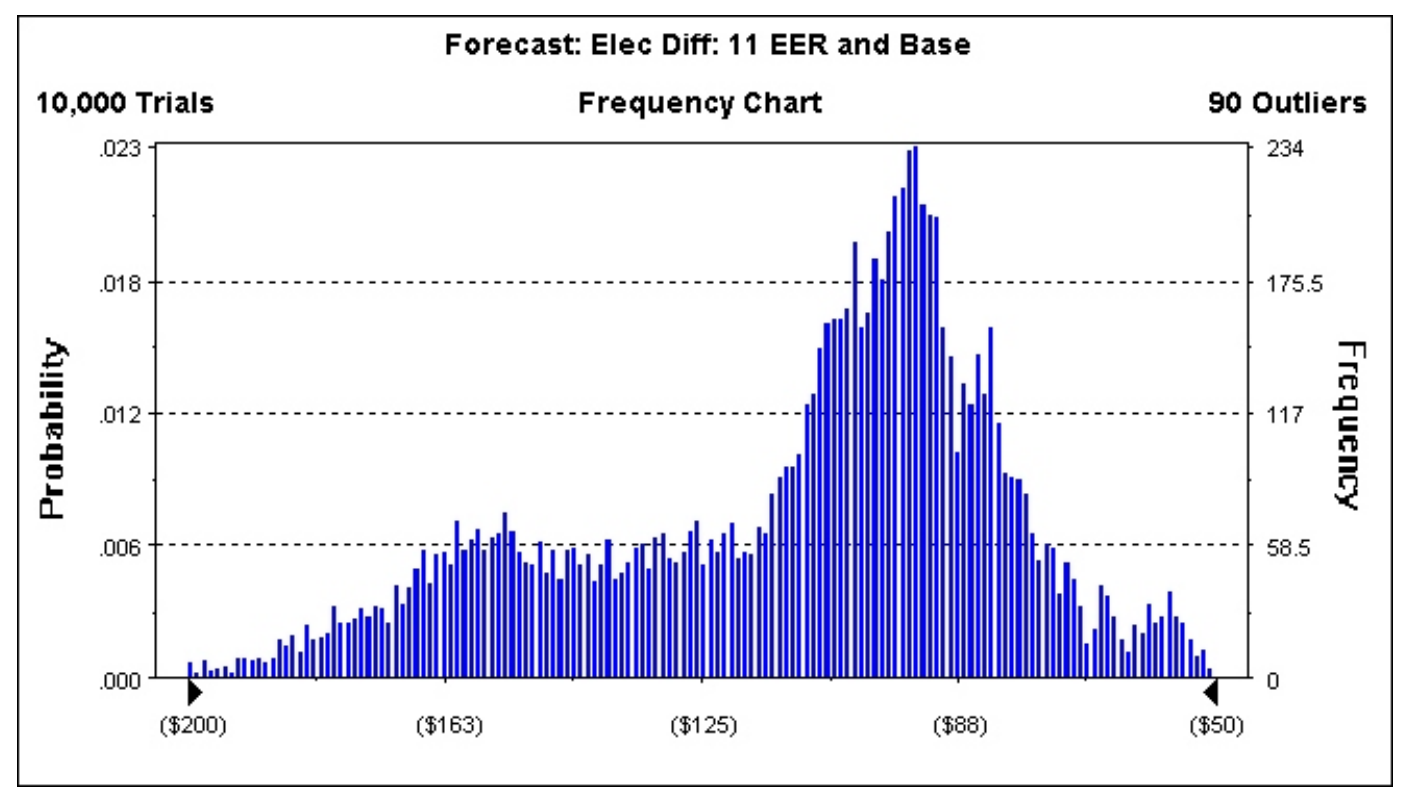

Figure $25 \geq 65,000 \mathrm{Btu} / \mathrm{h}$ to $<135,000 \mathrm{Btu} / \mathrm{h}$ : Hourly-Based Frequency Chart of Annual Energy Expense Differences between 11 EER and the Baseline (10.1 EER) 


\section{CONCLUSION}

This report described an analysis of the economic impacts of possible energy efficiency standards for commercial unitary air conditioners and heat pumps on individual customers in terms of two metrics: life-cycle cost (LCC) and payback period (PBP).

We used two approaches for determining customer electricity prices. The monthly approach calculates energy expenses based upon actual electricity prices which customers are currently paying. The hourly approach attempts to calculate energy expenses based upon electricity prices that customers may pay if electricity markets in the U.S. become deregulated. On a national-average basis, there is no significant difference in results between these two approaches.

For the $\geq 65,000 \mathrm{Btu} / \mathrm{h}$ to $<135,000 \mathrm{Btu} / \mathrm{h}$ equipment class and the $\geq 135,000 \mathrm{Btu} / \mathrm{h}$ to $<240,000 \mathrm{Btu} / \mathrm{h}$ equipment class, the 11.5 EER provides the largest mean LCC savings. The results show how the savings vary among customers facing different electricity prices and other conditions. At $11.5 \mathrm{EER}$, at least $80 \%$ of the users achieve a positive LCC savings. At 12.0 EER, the maximum efficiency analyzed, mean LCC savings are lower but still positive. For the $\geq 65,000$ $\mathrm{Btu} / \mathrm{h}$ to $<135,000 \mathrm{Btu} / \mathrm{h}$ equipment class, $59 \%$ of users achieve a positive LCC savings. For the $\geq 135,000 \mathrm{Btu} / \mathrm{h}$ to $<240,000 \mathrm{Btu} / \mathrm{h}$ equipment class, $91 \%$ of users achieve a positive LCC savings.

The mean payback period at 11.5 EER is 5 years for the $\geq 65,000 \mathrm{Btu} / \mathrm{h}$ to $<135,000 \mathrm{Btu} / \mathrm{h}$ equipment class and 4 years for the $\geq 135,000 \mathrm{Btu} / \mathrm{h}$ to $<240,000 \mathrm{Btu} / \mathrm{h}$ equipment class (using tariff-based prices). The paybacks are slightly shorter using hourly-based prices.

The LCC analysis indicates that new energy efficiency standards for commercial unitary air conditioners would meet one of the factors that DOE considers in determining whether economic justification exists for new standards. Specifically, it indicates that standards would result in savings in operating costs throughout the estimated average life of the product that are greater than the increase in the price of the product that is likely to result from the imposition of the standard. DOE will consider these results along with results from other parts of the larger analysis as its rulemaking for commercial air conditioners standards continues. 


\section{REFERENCES}

1. U.S. Department of Energy-Office of Building Research and Standards, Technical Support Document: Energy Efficiency Standards for Consumer Products: Residential Central Air Conditioners and Heat Pumps, 2000, U.S. Department of Energy. Washington, DC. Report No. LBNL-47463.

$<\mathrm{http}$ //www.eere.energy.gov/buildings/appliance_standards/residential/ac_central.html $>$

2. Westphalen D., and S. Koszalinski. April 2001. Energy Consumption Characteristics of Commercial Building HVAC Systems Volume I: Chillers, Refrigerant Compressors, and Heating Systems. Arthur D. Little, Cambridge, Massachusetts.

3. U.S. Department of Energy-Energy Information Administration, A Look at Commercial Buildings in 1995: Characteristics, Energy Consumption, and Energy Expenditures, October, 1998. Washington, DC. Report No. DOE/EIA-0625(95).

4. R.S. Means Companies, Inc., RS Means Mechanical Cost Data, 25 ${ }^{\text {th }}$ Annual Edition, 2002. Kingston, MA.

5. R.S. Means Companies, Inc., Means Facilities Maintenance \& Repair Cost Data 1995, 1995. Kingston, MA.

6. U.S. Department of Labor, Bureau of Labor Statistics, Industry - Refrigeration and Heating Equipment (3585), Product - Unitary Air Conditioners. Washington, DC. http://data.bls.gov/servlet/SurveyOutputServlet?jrunsessionid=103524171285521691

7. American Society of Heating, Refrigerating and Air-Conditioning Engineers, Inc. (ASHRAE), 1999 ASHRAE Handbook, Heating, Ventilating, and Air-Conditioning Applications, Inch-Pound Edition, 1999. Atlanta, GA. p. 35.3.

8. Bucher, M.E., C.M. Grastataro, and W.R. Coleman, Heat Pump Life and Compressor Longevity in Diverse Climates. ASHRAE Transactions, 1990. 96(1): p. 1567-1571.

9. Hiller, C.C., Predicting Future Heat Pump Production Volume Requirement using Equipment Survival Curves. ASHRAE Transactions, 1990. 96(1): p. 1572-1574.

10. Ibbotson Associates. Stocks, Bonds, Bills, and Inflation. 1999.

11. Ibbotson Associates. Stocks, Bonds, Bills, and Inflation. 1999.

12. Damodaran Online. Leonard N. Stern School of Business, New York University: http://www.stern.nyu.edu/ adamodar/New Home Page/data.html. January 16, 2002. 
13. Bureau of Economic Analysis. GDP price change: Q3, 2000 - Q3, 2001. http://www.bea.doc.gov/bea/glance.htm

14. Bloomberg Professional (December 12, 2001) and Bonds Online. http://www.bondsonline.com. January 22, 2002.

15. Federal Energy Regulatory Commission (FERC) Form 1 filings. http://www.ferc.fed.us/documents/forms/forms.htm. January 21, 2002

16. U.S. Department of Energy-Energy Information Administration, A Look at Commercial Buildings in 1995: Characteristics, Energy Consumption, and Energy Expenditures, October, 1998. Washington, DC. Report No. DOE/EIA-0625(95).

17. Ibbotson Associates. Cost of Capital Yearbook 2001.

18. Average cost of capital, after deducting 2.3 percent inflation, for a sample of service and retail companies. The estimate was obtained from the Bloomberg Professional service, during December, 2001.

19. Bloomberg Professional (December 12, 2001) and Bonds Online. http://www.bondsonline.com. January 22, 2002.

20. Ibbotson Associates. Stocks, Bonds, Bills, and Inflation. Valuation Edition. 2001. Page 14

21. Bonds Online. Treasury Yield Curve. http://www.bondsonline.com. January 2002.

22. Bond returns listed on the Damodaran online data site. Historical returns on stocks, bonds and bills. http://www.stern.nyu.edu/ adamodar/New Home Page/data.html. January 2002.

23. Ibbotson Associates. Stocks, Bonds, Bills, and Inflation. Valuation Edition. 2001. 